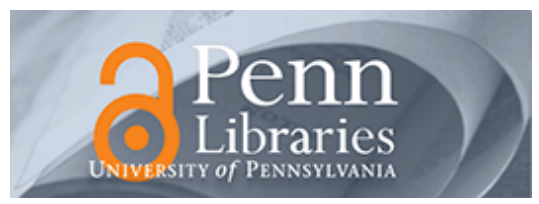

University of Pennsylvania

ScholarlyCommons

Management Papers

Wharton Faculty Research

$12-1-2014$

\title{
The Structural Elaboration of Board Independence: Executive Power, Institutional Logics, and the Adoption of CEO-Only Board Structures in U.S. Corporate Governance
}

John Joseph

University of Pennsylvania

William Ocasio

Northwestern University

Mary-Hunter McDonnell

Georgetown University

Follow this and additional works at: https://repository.upenn.edu/mgmt_papers

Part of the Management Sciences and Quantitative Methods Commons

\section{Recommended Citation}

Joseph, J., Ocasio, W., \& McDonnell, M. (2014). The Structural Elaboration of Board Independence: Executive Power, Institutional Logics, and the Adoption of CEO-Only Board Structures in U.S. Corporate Governance. Academy of Management Journal, 57 (6), http://dx.doi.org/10.5465/amj.2012.0253

This paper is posted at ScholarlyCommons. https://repository.upenn.edu/mgmt_papers/212

For more information, please contact repository@pobox.upenn.edu. 


\title{
The Structural Elaboration of Board Independence: Executive Power, Institutional Logics, and the Adoption of CEO-Only Board Structures in U.S. Corporate Governance
}

\author{
Abstract \\ This study builds on structural elaboration theory by developing a model to explain the adoption of board \\ structures that appear to conform to the prevailing institutional logic, but which in fact contradict it. We \\ test our theory with the case of CEO-only board structures, a formal increase in board independence that \\ prior research has shown to lead to greater CEO entrenchment rather than increased shareholder value. \\ Using an event history analysis of the Fortune 250 over a 27 -year period, we examine three mechanisms \\ that drive its adoption: executive interests, executive power, and elaboration opportunities. We show that \\ the CEO-only structure is more likely to occur in firms in which a higher proportion of insiders predate the \\ CEO, and in which the CEO has greater formal power and agenda control. We also find that powerful CEOs \\ are more likely to realize the structural change following institutional opportunities, such as the passage \\ of Sarbanes-Oxley (SOX), and organizational contingencies, such as positive changes in firm \\ performance. By exploring the mechanisms leading to the proliferation of the CEO-only structure, our \\ study contributes to sociopolitical perspectives on corporate governance, as well as to theories of \\ institutional logics and structural elaboration.
}

\section{Keywords}

board of directors, chief executive officer, ceo, corporate governance, institutional theory, power, sarbanes-oxley, sox, structural elaboration

Disciplines

Management Sciences and Quantitative Methods 
The Structural Elaboration of Board Independence:

Executive Power, Institutional Logics, and the Adoption of CEO-only Board Structures in

U.S. Corporate Governance

\author{
JOHN JOSEPH \\ Duke University \\ 100 Fuqua Drive \\ Durham, NC 27708 \\ 919-660-4083 \\ john.e.joseph@duke.edu \\ WILLIAM OCASIO \\ Northwestern University \\ 2001 Sheridan Rd \\ Evanston, IL 60208 \\ $847-467-3504$ \\ wocasio@kellogg.northwestern.edu
MARY-HUNTER MCDONNELL
Georgetown University
390 37th Street NW
202-687-4645
mhm62@georgetown.edu \\ Washington, DC
}

Forthcoming in Academy of Management Journal

We wish to thank Ithai Stern and Ed Zajac as well as participants at the Academy of Management, San Antonio for their comments on earlier versions of this work. We are also thankful for the feedback from Gerry McNamara and three anonymous reviewers. We are indebted to Nicole Ouellette, Sam Wilcock and Peter Park for their tireless help in data collection. 


\begin{abstract}
This study builds on structural elaboration theory by developing a model to explain the adoption of board structures that appear to conform to the prevailing institutional logic, but that in fact contradict it. We test our theory with the case of CEO-only board structures, a formal increase in board independence that prior research has shown to lead to greater CEO entrenchment rather than increased shareholder value. Using an event history analysis of the Fortune 250 over a 27year period, we examine three mechanisms that drive its adoption: executive interests, executive power and elaboration opportunities. We show that the CEO-only structure is more likely to occur in firms where a higher proportion of insiders predate the CEO and where the CEO has greater formal power and agenda control. We also find that powerful CEOs are more likely to realize the structural change following institutional opportunities like the passage of Sarbanes Oxley and organizational contingencies like positive changes in firm performance. By exploring the mechanisms leading to the proliferation of the CEO-only structure, our study contributes to socio-political perspectives on corporate governance as well as to theories of institutional logics and structural elaboration.
\end{abstract}


A key proposition underlying much of corporate governance research, both from agency theory and socio-political perspectives, is that inside directors are beholden to the CEO and that a greater proportion of inside directors on the board indicates greater CEO power and board control (Hermalin \& Weisbach, 1998; Lynall, Golden \& Hillman, 2003; Westphal \& Zajac, 1995). Underlying this proposition is the idea that outside directors can more capably monitor the CEO's activities, whereas inside directors are prone to capture and ill-equipped to contravene the CEO's inclinations (Hermalin \& Weisbach, 2003; Winter, 1977; Zajac \& Westphal, 1996). This view has widely influenced key institutional actors such as public interest groups, government regulators, and institutional investors in the United States. Beginning in the 1980s and continuing to the present day, these actors have successfully pushed for a decline in the number of inside directors on corporate boards (American Law Institute, 1982, Council of Institutional Investors, 1989, New York Stock Exchange, 2003).

The conceptualization of inside directors as pawns of the CEO is part of a broader concern with board independence and the rise of the institutional logic of shareholder value (Lok, 2010; Shipilov, Greve \& Rowley, 2010; Westphal \& Graebner, 2010). The shareholder value logic is based on agency theory, which holds that the sole purpose of the firm is to maximize shareholder value. The object of the board of directors is to ensure that the end of shareholder value maximization predominates over executive interests and entrenchment (Fama \& Jensen, 1983; Hermalin \& Weisbach, 2003). Accordingly, outside directors should hold a majority of the board's seats in order to effectively maintain decision control and sanction the CEO when needed (cf., Mizruchi, 1983). Thus the shareholder value logic specifies the 
relationship between the $\mathrm{CEO}$, insiders and outsiders on the board and the rationale for board independence as a mechanism to align the interests and actions of management and shareholders.

The rise of the shareholder value logic and the concomitant increase in board independence has led to a supermajority of outside directors in U.S. corporate boards (Spencer Stuart, 2011). However, less recognized is the rising number of corporations in which the CEO is the only insider in the board - what we refer to as the CEO-only structure (c.f., Adams, Almeida \& Ferreira, 2005). Although increasingly prevalent, neither agency theory, nor regulatory, stock exchange or professional standards call for the CEO-only structure. In fact, CEO-only boards have proliferated in direct contravention to calls to separate the CEO and the Chairman positions (e.g., Rechner \& Dalton, 1991; Brickley, Coles \& Jarrell, 1997; Finkelstein, Hambrick \& Cannella, 2009), which have not been widely heeded (Spencer Stuart, 2011).

While CEO-only boards may appear to be a natural outgrowth of the pursuit of board independence, their increasing prevalence is also somewhat paradoxical. Recent research by both finance and management scholars suggests that the CEO-structure actually increases a CEO's power and influence. For example, the CEO-only structure leads to diversification discounts (Hoechle, Schmid, Walter\& Yermak, 2012), monitoring inefficiencies (Liu \& Jiraporn, 2008), and greater CEO influence (Adams et al, 2005). Unlike other structural and practice reforms that were prompted by the shareholder value revolution throughout 1980s and 90s (e.g., Davis \& Stout, 1992; Davis et al, 1994; Fligtein, 2001; Fligstein \& Markowitz, 1993, Zuckerman, 2000), these more recent findings provide evidence that CEO-only boards actually contradict agency theory's prescriptions by enhancing CEOs' entrenchment and interests. Given evidence that CEOs in U.S. corporations have circumvented the limits on their control imposed 
by the diffusion of the shareholder value logic through a variety of mechanisms (Davis, 1991; Westphal \& Zajac, 1995; Westphal, 1998; Westphal \& Khanna, 2003; Goldstein, 2012), this begs the question: What role has the CEO played in determining the CEO-only board?

To explain the paradoxical spread of the CEO-only board structure, we draw from and extend structural elaboration theory (Edelman, 1992) and apply it to analyze the adoption of the CEO-only structure. In Edelman's (1992) original formulation, the theory referenced how legal mandates were often ambiguous, allowing organizations to adopt formal structures that appeared to conform, while designed instead to foster managerial interests. We extend the theory to the context of institutional logics (Friedland \& Alford, 1991; Thornton, Ocasio, \& Lounsbury, 2012) and argue that institutional logics are also ambiguous with respect to the specifics of formal structures, allowing for political processes to shape their structural implementation. Logics create pressure for structural reform, but the precise way that an organization structurally responds to this pressure depends on three mechanisms: executive interests, executive power, and elaboration opportunities.

Executive interests and power, both of which are displayed at the board level, are intimately connected in this process. Powerful organizational elites strategically respond to new logics, seeking to adopt structures that ostensibly conform to the logic but that function in practice to promote their own interests. Whereas conventional wisdom on inside directors would suggest that the CEO-only structure diverges from CEO interests, we argue that, compared to other variants of independent majority structures, the CEO-only structure advances the interests of CEOs by conferring an information brokerage position and eliminating potential internal contestants for their power and position. Thus we propose that powerful CEOs strategically 
respond to institutional pressure for board independence and support the CEO-only structure, an elaborated version of board independence. The third mechanism we propose, elaboration opportunities, can occur at either the organization or the institutional level. Elaboration opportunities are events or contingencies that allow organizational elites to leverage their power and influence structural change. Whereas the first two mechanisms help to explain why a particular structure proliferates in response to a newly dominant logic, this final mechanism helps to explain when structural elaboration is most likely to occur. Ultimately, the confluence of logics, elaboration opportunities, individual interests and power create decision-making situations that allow for political activity and instigate processes of structural elaboration. Empirically, we test our theory with a study of the adoption of the CEO-only structure by Fortune 250 firms from 1981 to 2007 . Throughout this period, the regulatory governance of boards went through extreme shifts and the logic of shareholder value became increasingly dominant. From our longitudinal vantage, we are afforded a unique opportunity to observe how shifts in institutional environments and organizational contexts interacted with the distribution of CEO power to influence the emergence and diffusion of the CEO-only structure.

Our study offers several contributions. First, we contribute to the socio-political literature on corporate governance (Westphal \& Zajac, 1995; Lynall, Golden \& Hillman, 2003; Combs, Ketchen, Perryman, \& Donahue, 2007). We build on prior research establishing that governance structures and policies are symbolically manipulated by corporate leaders in order to signal conformity with shareholder values while causing minimal disruptions to the actual balance of power within the corporation (Fiss \& Zajac, 2004, 2006; Porac, Wade \& Pollock, 1999; Westphal \& Graebner, 2010). We extend this line of research by challenging conventional 
wisdom that CEOs will always prefer inside directors to outsiders, showing instead that the greater the power of the CEO, the greater likelihood of adoption of a CEO-only structure. We propose that this structure offers CEOs informational brokerage advantages relative to outside directors and increases their status and power inside the organization.

Second, we contribute to the institutional logics literature by highlighting the role of power in the elaboration of institutional logics. While the role of power has been established in prior theory and research in institutional logics, it has not been the main focus of this conversation (cf. Thornton \& Ocasio, 2008). Prior research has focused on either how institutional logics shape the determinants of power (e.g., Thornton \& Ocasio, 1999), or how competition between alternative institutional logics is shaped by power struggles between individual and collective actors (Marquis \& Lounsbury, 2007; Meyer \& Hammerschmid, 2006; Reay \& Hinings, 2009). The theoretical and empirical focus of this paper -- how executive power shapes structural responses to institutional logics -- has received limited research attention.

Third, we contribute to structural elaboration theory. Edelman's (1992) account of elaboration vests structural change in the interaction of regulatory shocks and organizational interests. Her theory proposes that organizations strategically react to regulatory shifts by implementing formal structures that further their own interests while signaling conformity to institutional expectations. Our study extends this theory by discussing its application in the broader context of institutional logics. Moreover, we draw from socio-political theory to explore the intra-organizational political dynamics that undergird the process of structural elaboration.

\section{THEORY}


Our theory of board structure and composition combines a socio-political perspective on corporate governance with an examination of changes in institutional logics (Zajac \& Westphal, 1996; Thornton \& Ocasio, 1999; Green, Babb, \& Alpaslan, 2008). Institutional logics provide historically contingent organizing principles and vocabularies of practice that shape individual and organizational values, beliefs, and behavior (Thornton et al., 2012). During the 1980s, a logic of shareholder value revolutionized the institutional field of corporate governance (Fligstein and Shin, 2007; Greenfield, 2012). This logic was ideologically rooted in agency theory (Fama \& Jensen, 1983; Jensen \& Meckling, 1976) and promoted shareholder wealth maximization as the guiding principle for corporate managers and boards of directors. In light of the logic, corporate leaders were urged to take necessary steps to align managerial incentives with the interests of the firm's stakeholders (Fligstein and Shin, 2007). Organizational theorists have extensively documented the logic's impact on U.S. corporations throughout this period, as it promoted widespread corporate reorganizations, revisions to employment processes, and amended governance structures (Davis, 2009; Davis, Diekmann and Tinsley, 1994; Davis and Thompson, 1994; Useem, 1993; 1996; Zorn et al., 2005). The shareholder value logic has also shaped corporate governance practices in other countries, but not uniformly so (cf., Fiss and Zajac; Lok, 2010; Shipilov et. al., 2010). One particularly ubiquitous change spurred by the logic was the rise of board independence, which was prescribed as a mechanism for monitoring the CEO to assure that their decisions aligned with shareholders' interests. At the same time, reformers challenged the insider-dominated boards that were characteristic of the previously dominant managerial logic by questioning their monitoring capabilities (Mizruchi, 1983; Weisbach, 1988). 
While institutional logics provide the guiding principles for organizational structures and practices, they do not provide detailed templates for organizing, but instead allow substantial variation in their implementation (Ansari, Fiss, \& Zajac, 2010; Lounsbury, 2001, 2008). Prior research has identified both conforming and anomalous practice variation, but has focused largely on the latter, holding that anomalous variations lead to changes in institutional logics both within and across organizations (Lounsbury, 2007; Thornton et al, 2012). One exception is the study by Shipilov et al. (2010), which studied second wave adoption of board governance practices in Canada, following the adoption of the logic (and practices) of board reform. They find that second wave adoption of appropriate forms of variation is positively influenced by firmlevel adoption of practices from the same institutional logics.

Structural elaboration theory provides a new lens to explain why particular practices are developed and adopted in response to new institutional logics. Structural elaboration theory proposes that laws often set forth broad and ambiguous principles, subject to interpretation by organizational actors (Edelman, 1992). Organizations respond to legal requirements by elaborating formal structures that serve as visible symbols of compliance, but are not always responsive to the intended purposes of the law. The theory additionally holds that organizational interests drive the interpretation of law and lead to variations in the structural forms (formal rules and organizational structures) by which the law is implemented. Specifically, the theory contends that organizations strategically react to institutional mandates by searching for structural forms that signal compliance but, in practice, protect and promote the interests of powerful internal elites. Structural elaboration theory has been developed and tested primarily in the context of Civil Rights Law and the employment relationship (Edelman, 1992; Kalev \& 
Dobbin, 2006: Kmec \& Skaggs, 2009), but has not yet been applied to explain variations in corporate governance structures or institutional logics.

Like structural elaboration theory, the institutional logics perspective has highlighted the role played by interests in the adoption of organizing practices (Thornton et al, 2012). But the focus of theory and research has been on how power and interests shape competition and rivalry among alternative institutional logics (Levy \& Scully, 2007; Marquis \& Lounsbury, 2007; Reay \& Hinings, 2009) or how they lead to the transformation and change in logics (Greenwood \& Suddaby, 2006; Nigam \& Ocasio, 2010; Seo \& Creed, 2002). Structural elaboration theory adds to the institutional logics perspective by emphasizing that power and interests can lead to the adoption of a particular variant of a practice that apparently reinforce existing logics, yet actually work in practice to contradict underlying theoretical principles.

In this paper, we extend and modify structural elaboration theory by proposing a model to explain the adoption of structures that symbolically conform to prevailing institutional logics, but in fact, do not. Our model incorporates three interrelated mechanisms: executive interests, executive power, and elaboration opportunities. According to our theory, the adoption of formal structures and practices that appear to reinforce prevailing institutional logics varies across organizations and over time. We expect the variants that proliferate to be those that align with the interests of powerful executives, in our case the CEO (cf., Finkelstein, 1992; Pfeffer, 1981). The timing of the adoption of specific variants will be shaped by environmental events and organizational contingencies (cf., Zajac, Kraatz \& Bresser, 2000). These create elaboration opportunities that increase the likelihood of adoption of structural variants consistent with both 
the prevailing institutional logics and the interests of powerful executives (cf., Kingdon, 1984; March \& Olsen, 1976).

We test our theory via a longitudinal analysis of U.S. firms' adoption of the CEO-only insider board structure, a symbolic corporate governance structure that elaborates the shareholder value logic in the United States. Board independence is a guiding principle of the shareholder value logic, which propones that independent outside directors are better monitors of firm managers and the CEO (American Law Institute, 1982, Daily, Dalton \& Cannella, 2003; Rosenstein \& Wyatt, 1990). While this principle indicates that a majority of the members of the board should be outsiders without financial ties to the organization, no further specification is universally agreed upon. This vagueness allows organizations considerable latitude in deciding how exactly to implement the principle of board independence. Possible variants in implementation include, for example, the separation of the CEO and Chair position (Dalton \& Kesner, 1987; Westphal \& Zajac, 1997), appointment of lead directors (Sonnenfeld, 2004), fully independent audit committees (Coates, 2007), and supermajority outsider boards (Jensen, 1993). Although these variants are symbolic manifestations of compliance with the principle of board independence, their effectiveness in achieving the intended goal of maximizing shareholder value is at best equivocal. Overall meta-analysis of the effects of board independence on financial performance shows lack of consistent effects (Dalton, Daily, Ellstrand, \& Johnson, 1998). And despite the earlier theoretical support for supermajority outsider boards among agency theorists (e.g, Jensen, 1993), empirical support for their superiority is also limited (Bhagat \& Black, 2001). 
The CEO-only insider board is itself a variant of supermajority outsider boards. While the selection of insiders vs. outsiders is typically considered a question of board composition rather than structure, having the $\mathrm{CEO}$ as the only insider on the board alters the formal and informal structural relationship between the CEO, other firm executives, and outside directors, in ways that other forms of supermajority outsider boards do not. The CEO-only structure uniquely privileges the role of the chief executive in that it creates a structural hole between the organization and the board of directors, which the CEO can then fill (Burt, 1992). By being the only insider on the board, the CEO becomes the exclusive formal conduit of information between management and the board of directors. As no other firm executives are peers of outside directors as board members, it also reduces the opportunities for informal interactions between outside directors and other firm executives. This structural change increases the board's dependence on the CEO, in turn augmenting the CEOs' influence and perceived value. By extension, the structure reduces the status and formal power of other senior managers, removing them as contestants for the CEO's power and position (Ocasio, 1994). Therefore, the CEO-only structure is critically distinguishable from other forms of independent-majority boards in that it qualitatively alters the structural relationships between the CEO, outside directors and other senior executives.

The role of the CEO in fostering the adoption of the CEO-only structure is illustrated by Lou Gerstner's mobilization of power at IBM. When Gerstner became CEO in 1993, the board included three other inside directors. By the start of 1995, only Gerstner remained. The CEOonly structure remained intact at IBM throughout Gestner's tenure and prevailed until 2012, when Virginia M. Rometty became CEO, succeeding Sam Palmisetto who remained on the 
board for one year as Chairman. According to Gerstner's own account, he was concerned with the power of inside directors on the board and mobilized the support of outsiders to reduce the size of the board and eliminate all other inside directors (Gerstner, 2002: 75-76):

"One of the most revolutionary, but least noticed, changes in the early days involved the Board of Directors. When I arrived there were eighteen directors, including four insiders...I thought this was an unwieldy size with too many insiders, particularly given the dominance of current and former employees on the powerful Executive Committee. ...Clearly the CEO search, the media's public flogging of the company, and the sharp, extended criticism at the annual meeting had traumatized many members of the board. I quietly approached a few of them, especially Jim Burke and Tom Murphy, for a series of discussions on corporate governance... With my encouragement, the Director's Committee decided it would announce that the board should be reduced in size to make it more manageable. At the same time, we would add new people to bring in some different perspectives. After the announcement, it didn't take anyone more than a minute to realize that meant a significant amount of retirements would be in order. ... By the end of 1994, we had a twelve-member board. I was the only insider. Only eight remained form the eighteen who had made up the board just year before."

As this account illustrates, Gerstner relied on principles of corporate governance to mobilize support for changes in the board's structure and composition, including the adoption of a CEOonly. In particular, Gerstner's actions imply that the removal of insiders aligned with his own interests in that he was able to remove senior managers that had social capital with outside directors (an asset that he, as newcomer to IBM and its board, had yet to develop), and that had formal power through membership in the board and its executive committee. By removing powerful executives from the board, Gerstner managed to increase his relative power on the 
board and eliminate potential contestants for his power and position. His ability to do so during a period of increasing performance indicates an underlying opportunity to advance his interests and influence. In what follows, we explore each of these themes in greater detail and develop hypotheses for each of the mechanisms driving CEO-only structure adoption.

\section{Hypotheses}

Executive interests. Shifts in institutional logics often compel firms to change their practices or structures in order to conform to changing institutional expectations. Structural elaboration theory suggests, however, that organizational responses to new institutional demands do not always represent "a good faith effort to comply" with the underlying impetus of an institutional shift (Edelman, 1992: 1567-1568), but are instead often symbolic (Edelman, 2992; Fiss \& Zajac, 2006; Westphal \& Zajac, 1994). Understanding why particular structures and practices proliferate in response to an institutional shift requires an examination of the interests of the actors within organizations (Edelman, 1992; Fox-Wolfgramm, Boal, \& Hunt, 1998; Kellogg, 2009). Edelman (1992) further suggests that organizations respond to institutional shifts by adopting formal structures that symbolically comply with new institutional demands but also protect the interests of the elites within them. In light of this, our present effort to explore the rise of the CEO-only structure in response to the shareholder value logic begins with an assessment of how the structure simultaneously signals compliance with the logic and promotes the CEO's interests.

The CEO-only structure provides an especially strong signal of compliance with the shareholder value logic, as it requires the removal of all insiders from the board, aside from the 
CEO, who are, according to the agency perspective, beholden to CEO interests (Hermalin \& Weisbach, 2003; Winter, 1977). We assert, however, that the CEO-only structure works in practice to promote the CEO's interests in three distinct ways. Foremost, in the CEO-only board structure, the CEO becomes the information broker between the senior executives of the corporation and members of the board of directors, providing the $\mathrm{CEO}$ with a unique informational advantage. Network scholars have long noted the inherent benefits of a brokerage position between two disconnected parties (Burt, 1992; 1997). Brokers may control the diffusion of nonredundant information between separate groups and benefit from a disproportionate say in whose interests are served when the groups come together. Potentially, this increases the relative dependence of outsiders and insiders on the CEO and, consequently, the CEO's power over both parties (Burt, 1997). In the absence of insiders, the CEO can use the brokerage role to regulate the flow of information on the firm's financial and strategic issues. Outside directors are dependent on the CEO and other top managers for detailed knowledge and information on the firm's strategy, operations, and financial performance. This information is particularly important for outside directors, whose time and attention is limited, as their board membership is most often a secondary employment (Pfeffer and Salancik, 1978; Westphal, 1999). Insider board membership provides outside directors with more direct access to internal information. Without other insiders on the board, outside directors are less likely to be exposed to ideas about the firm's strategy and performance that differ from those of the CEO. Thus the brokerage position afforded by the CEO-only structure is likely to amplify the CEO's control over critical board decisions. It is also likely to increase the other directors' reliance on the CEO and lead them to view the $\mathrm{CEO}$ as more valuable, which is supported by empirical evidence that CEOs within a 
CEO-only structure are compensated more highly than CEOs on boards with other insiders (Zorn et al., 2013). ${ }^{1}$

Second, the CEO-only structure increases the CEO's status and power relative to other corporate executives. Boards of directors are elite decision-making groups; board membership comes with direct status and power benefits for inside directors (Finkelstein, 1992; Forbes \& Milliken, 1999; Main, O’Reilly, \& Wade, 1995). An insider's loss of (or inability to secure) a board position may affect their reputations outside as well as inside the company. By being the only insider on the board, the CEO is advantaged with a source of power and status that other insiders lack, increasing their relative power.

Third, the CEO-only structure removes contestants for the CEO's power and position by eliminating potential heirs apparent from the board (Ocasio, 1994; Shen \& Cannella, 2002). Moreover, the CEO-only structure increases the CEO's control over other executives' exposure to the board. CEO candidates often gain exposure to the board of directors through board membership (Vancil, 1987). Membership provides outside directors with a chance to see executives in action and evaluate their performance in managing the critical issues of the firm and to compare them to the CEO. However, in the case of the CEO-only board, executive's access to the board is, for the most part, contingent on the CEO's granting them access. As a result, the CEO's increased control over the exposure that other executives have to the board

${ }^{1}$ While the present paper is concerned primarily with exploring the antecedents of the CEO-only structure rather than its effects, we have also replicated prior studies of how CEO-only structures increases CEO compensation and $\mathrm{CEO}$ entrenchment with our unique dataset. The results are available from the first author. 
may shift the dynamics of the succession process to favor the CEO's preferences and limit access to internal contenders for the CEO position (Ocasio, 1994; Shen and Cannella, 2002).

Consequently, a CEO-only-insider structure may increase the CEO's influence within the CEO selection and succession process. Additionally, by removing the potential for a vetted internal heir apparent, the structure makes it more difficult for the board to remove the CEO, increasing CEO entrenchment.

Insofar as the CEO-only structure is perceived by CEOs as being in their interest, structural elaboration theory suggests that CEOs should respond to the proliferating shareholder value logic by pushing their firms to adopt this structure in symbolic compliance. Of course, while theoretical and empirical evidence demonstrate that the CEO-only structure does advantage CEOs, CEOs may not always recognize the CEO-only structure as preferable to a simple or supermajority independent board. Consequently, we contend that the extent to which a CEO will be motivated to remove other insiders from the board depends in part on whether the CEO recognizes other insiders as being allies or contestants. The CEO's interests in adopting the CEO-only structure are thus shaped by variations in the composition of inside directors on the board.

While some inside directors may be staunch allies of the CEO, prior research suggests that some insiders may contest the CEO's power (Ocasio, 1994). Extending this notion, we propose that inside directors whose appointments predate the $\mathrm{CEO}$ are more likely to be political contestants of the CEO than those who postdate the CEO. Prior work suggests that a CEO is more likely to have close ties with inside directors appointed during his or her tenure (Kim \& Cannella, 2008). Additionally, a CEO is less likely to be committed to inside directors who were 
appointed by a predecessor, and they are less likely to obtain these directors' support, compared to directors who they helped to appoint (Johnson, Schnatterly, \& Hill, 2013). Predating insiders are also more likely to have been rival candidates for the CEO's position (cf., Vancil, 1987), enhancing the likelihood that they are political contestants to the CEO rather than allies. We suggest, therefore, that CEOs are most likely to recognize the CEO-only structure as being in their interests when, as in the Gerstner example discussed above, the other insiders on the board predate the CEO. Thus, we hypothesize the following:

Hypothesis 1: The greater the proportion of inside directors appointed prior to the selection of the current CEO, the more likely the adoption of a CEO-only board structure.

Executive power. Structural elaboration theory, with its focus on organization-level outcomes, treats elites' ability to influence change as being uniform across populations of organizations. However, not all CEOs are uniformly able to influence board structural reform (Zajac and Westphal, 1996). The socio-political perspective suggests that CEOs' ability to influence their organizations depends on the power they exercise relative to other elite constituencies. As CEO power increases, it becomes more likely that the CEO will influence a firm's board structure and composition (Lynall et al., 2003; Westphal \& Zajac, 1995). By grafting structural elaboration theory to the socio-political perspective, we propose a more nuanced model of the mechanisms driving processes of structural elaboration (Harris et al., 2013). Our theory diverts from prior work in the socio-political tradition, however, by hypothesizing that powerful CEOs may favor a structure that eliminates all insiders on the board, rather than increases them. 
With the proliferation of the agency logic and its demands for enhanced board independence over our period of study, insider-dominated boards were no longer an available option for corporate CEOs. Instead, boards were pressured to signal their conformity to the logic by having a majority of independent directors. Within independent majority structures, the CEO is less benefitted by having insiders on the board, as the support of outsiders is necessary to achieve majority support (Bhagat and Black, 2001). And, as noted above, the CEO-only structure uniquely benefits CEOs by providing them with an information brokerage position and limiting contestation from other executives. Therefore, CEOs responding strategically to the shareholder value logic may press for the CEO-only structure as preferable to other variants of independent-majority structures.

Mobilization of the CEO's power in support of the CEO-only structure is likely to be a function of the CEO's agenda control and influence over the nominating process rather than of an overt conflict with other board members. Outsiders are likely to side with a powerful CEO in favor of the structure because of its consistency with institutional demands for a stricter board. While board members are technically nominated by a nominating committee made up of independent directors, in reality board membership commonly comes via an invitation from the CEO (Roe, 1994). This makes the CEO's power and influence particularly important for structural elaboration in the board setting.

Following Finkelstein (1992), we consider three aspects of the CEO's power: duality, stock ownership, and functional background. CEO duality increases the CEO's agenda and information control, shaping which issues the board considers and how it evaluates them. Furthermore, because dual CEOs also serve as Board Chair, duality increases the CEO's formal 
authority over board composition. CEO power also increases with high relative stock ownership, which affords greater influence through voting rights (Zald, 1969). If the CEO holds a disproportionate percentage of company stock, she reduces the relative provision of resources by other directors, alleviates attention given to monitoring by outsiders and advantages her agenda.

Functional background may also serve as a source of power. In particular, CEOs with a finance background are especially situated to provide information to the board that would otherwise be provided by the CFO or other key insiders: information on major capital investments, financing, and major transactions (Davis, Diekmann, \& Tinsley,1994). Finance CEOs are better equipped to answer investor demands for greater disclosure of corporate financial information (Matsunaga \& Yeung, 2008) and have a greater opportunity to do so in absence of CFOs. Correspondingly, a finance background may better orient the CEO towards the greater monitoring requirements associated with the shareholder value logic and concomitant elaborations in board structure. In all, we suggest that structural elaborations that conform to prevailing institutional logics while enhancing CEO interests are more likely the more powerful the CEO.

Hypothesis 2: The greater the power of the CEO in the board, the more likely the adoption of a CEO-only board structure.

Elaboration opportunities. In the original development of structural elaboration theory, the coercive effects of institutional shocks in the form of new legislation led to the adoption of new symbolic structures. Extending the theory to examine variations in structures that reinforce a prevailing institutional logic, we suggest that both environmental events and organizational contingencies may trigger opportunities for change (Meyer, 1982; Zajac et al., 2000: Thornton et 
al, 2012). These elaboration opportunities moderate the impact of the interest and power mechanisms discussed previously. Specifically, elaboration opportunities trigger increases in the power of particular elites within a firm, offering them a window in which to influence structural elaboration in accordance with their own interests. In this way, elaboration opportunities help to explain when structural change is most likely to occur in the process of structural elaboration.

Given limitations on the issues that executives can attend to at any given time, the consideration of alternative governance structures is likely to wax and wane in the organization's agenda (March \& Olsen, 1976; Ocasio, 1997). Institutional-level changes in an organization's environment provide elaboration opportunities that shape the timing of the adoption of structural variants. In the context of the shareholder value logic, following the Enron and WorldComm scandals, the adoption of Sarbanes Oxley legislation significantly affected the language and practice of corporate governance (Gordon, 2007). The passage of Sarbanes Oxley (SOX) triggered a new regime of corporate governance, where board independence received increasing board attention. Soon after SOX, board independence was further promoted when the major U.S. stock exchanges all introduced rules requiring listed companies to have a majority of independent directors on the board (Chhaochharia \& Grinstein, 2007). In particular, the passage of SOX increased the importance of board members with financial expertise who can capably monitor corporate financial reports. The two primary demands of the law -- mandating independent audit committees and requiring CEOs and CFOs to personally certify financial statements - are intended to foster greater financial scrutiny. After SOX, therefore, the power and perceived importance of CEOs with financial backgrounds was likely enhanced. 
Insiders with a particularly unique set of skills or knowledge may increase the relative dependence that other board members have for them, particularly when those skills are in an area critical to the firm (Hickson, et al., 1971). This suggests that the introduction of SOX within organizations' institutional environments likely engendered shifts in the political dynamics within boards, augmenting the power of CEOs with financial backgrounds. CEOs with financial expertise likely leveraged their increased power, influencing their companies to adopt board structures that best promoted their interests. Thus, we hypothesize:

Hypothesis 3: In the post SOX-period, CEOs with financial backgrounds will increase the likelihood of adopting the CEO-only structure.

While structural elaboration theory has singularly focused on elaboration opportunities occurring at the institutional (and specifically formal, or regulatory) level, we suggest that elaboration opportunities also occur at the firm level. Recent theoretical developments in the institutional logics perspective support this view, as situational contingencies activate highly accessible institutional logics, in this case the shareholder value logic, and facilitate change in organizing practices (Thornton et. al. 2012). Particular organizational contingencies can become elaboration opportunities when they provide powerful elites with a window within which to enact changes that reflect their own interests as well as the prevailing logic. Such is the case when firm performance increases during the tenure of a particular CEO.

Unlike structural dimensions of power like CEO duality or relative shareholdings that increase a CEO's power by directly augmenting their control over board decisions, performance increases are not inherently a source of board power for CEOs. However, positive changes in firm performance create an elaboration opportunity because a favorable change in performance is 
likely to draw attention to the CEO's success and increase the board's evaluation of the CEO's effectiveness, thereby increasing the CEO's influence on new board initiatives. A CEO who is successful at improving the firm's performance will be viewed as having a firm grasp on current environmental demands and internal challenges. In these situations, the CEO's solutions to organizational problems, whether or not they are actually responsible for the performance increase, become highly valued by the board and gain credence with external monitors like industry analysts and the media (Hayward, Rindova and Pollock, 2004). Because the CEO's interests, strategies and actions will be viewed as aligned with shareholders and in support of shareholder value, the board is likely to grant greater discretion to the CEO in shaping board decisions (including that of board membership). Note that at the time of IBM's transition to CEO-only discussed above, Gerstner was well into a successful turnaround effort to cut billions in expenses and raise cash by selling assets. Thus, performance increases generate opportunities for CEOs to mobilize power over board members and affect changes consistent with their interests.

This notion receives additional support within corporate governance research, where evidence suggests that performance plays a significant role in processes of structural change (Cannella \& Shen, 2001; Finkelstein \& D’Aveni, 1994). Illustratively, Cannella and Shen (2001) documented that powerful CEOs are more likely to remove potential rivals when their firms perform well. While their study focused on heirs apparent, this effect is likely to generalize to independent majority structures where the CEO would be empowered by being the only insider on the board. For powerful CEOs, positive changes in firm performance provide 
opportunities to adopt structures consistent with both their interests and prevailing institutional logics. Thus we hypothesize:

Hypothesis 4: The greater the increase in firm performance, the greater the effect of CEO power on the likelihood of adoption of CEO-only structures.

\section{METHODS}

\section{Sample and Data Collection}

This study uses an event history design to examine the adoption of the CEO-only insider structure. The population for this study includes the largest U.S. firms, as listed in the 1995 Fortune 250. We chose this year because it is the first year that Fortune magazine included both industrial and service companies in its listings. Given the lack of financial data for 28 of the companies in the original sample, the sample was reduced to 222 companies. T-tests on the initial and final samples indicated no significant differences in size, measured as log of sales.

Our unit of observation is the company-year for every company in the population covering the years 1981-2007. Prior research suggests that during this period corporate governance -- and board structure in particular -- rose to prominence as a key concern for corporate stakeholders and regulators in the U.S. The timeframe covers three important periods: the rise of the institutional investors during the late 1980s and early 1990s (Davis \& Thompson, 1994), the scandalous collapses of Enron and Worldcom during 2001, and the following shift in the regulatory environment engendered by the adoption of Sarbanes-Oxley. Some firms were founded or became publicly held after 1981 and many merged or otherwise ceased to be publicly held companies prior to 2007. The methodology treats any spells ending prior to 2007 as right 
censored at that point. Data on insiders and the board of directors were obtained from the Standard and Poor's Register of Corporations, Directors and Executives, Who's Who in Finance and Industry and corporate proxy statements. Revenue, employee data, and other financials were obtained from COMPUSTAT. All independent variables and controls are lagged. Because of this lag, we omitted all years in the data in which succession occurred so that the variables we use to capture CEO power would always reflect the sitting CEO at each firm, rather than the prior CEO. The final sample includes a total of 2,918 firm-years.

\section{Dependent Variable}

To analyze the likelihood of a transition to CEO-only insider status, we created a dichotomous variable, coded as "1" in a given year if the number of inside directors decreased from two or more insiders to only one insider (the CEO) and " 0 " otherwise. Transitions to the CEO-only insider structure were considered from 1981-2007, and were coded from Standard and Poor's Register of Corporations, Directors and Executives based on the publication's indication of insider status. Family members, for our purposes, were also considered insiders. Firms are at risk of adopting the CEO-only structure only if they have at least one insider on the board in addition to the CEO for at least one year. In our analysis, we sought to distinguish between short-term CEO-only structures and longer-term shifts that demonstrated an effort to create a permanent CEO-only structure. Therefore, to avoid short-term perturbations in board structure, we only considered a firm as having a CEO-only structure if it lasted for more than two years. Two years provides ample time for boards to re-appoint insiders (if they are so inclined) and sensitivity analysis suggests that three and four year durations do not substantially change the findings. In total, 144 events were observed within the 2,918 company-years of data in the 
sample. Figure 1 shows the percentage of firms in the Fortune 250 that had the CEO-only structure over the duration of the study. Whereas only around $5 \%$ of firms had the firm in the first year of our panel, over half of firms possessed the structure by the last end of the panel.

[Insert Figure 1 about here]

\section{Independent Variables}

Proportion of insiders appointed before the CEO. To test our first hypothesis we include a control for the proportion of inside directors other than the CEO who obtained their board seats at any time prior to the current CEO's arrival.

CEO power. We utilize three measures of CEO power to assess the effects of CEO power on the creation of the CEO-only board. This is consistent with prior suggestions that CEO power is multidimensional. For example, Finkelstein (1992) developed and validated a set of four dimensions of CEO power based on a variety of factors such as hierarchical position, stock ownership and functional expertise. A number of subsequent studies have utilized derivatives or subsets of the Finkelstein power measures to explore a host of outcomes (e.g. Cannella \& Shen, 2001,Bigley \& Wiersama, 2002). We follow Finkelstein and colleagues and utilize three of his key measures of CEO power: functional background, duality, and stock ownership. We do not rely on CEO tenure as a measure of power because of the confounding effects of impending succession. As a CEO's tenure increases, boards are more likely to add inside directors as heir apparent to the CEO (Vancil, 1987; Hermalin \& Weisbach, 1998; Shen \& Cannella, 2001). However, we do control separately for a CEO's relative tenure, as described below.

CEO duality is included as a binary variable, coded " 1 " if a CEO is also the board chairman. This is one of the most widely used measures of CEO power (Wade et al., 1990), 
argued to increase the CEO's ability to control board agendas (Finkelstein \& D'Aveni, 1994) and afford the CEO unity of command in complex environments (Boyd, 1995).

High levels of CEO stock ownership directly afford CEOs power through enhanced voting rights (Zald, 1969). Because stock is also an important source of power for directors (Zajac \&

Westphal, 1995), we use a relative measure of CEO stock ownership, calculated as the number of outstanding shares held by the CEO divided by the total number of outstanding shares held by all board members. CEO finance background was determined using the Forbes annual compensation survey. Given that financial expertise is particularly critical for evaluation of firm performance, we expect CEOs with financial backgrounds to be more likely to mobilize their power to secure a CEO-only structure. We created a binary variable that was coded " 1 " if a CEO had a background in finance.

Sarbanes Oxley and its elaboration. We incorporate a period effect for Sarbanes Oxley (SOX) in the model. The SOX variable is binary, coded " 1 " for the years 2003 and after, after the law went into force. To test the elaboration of SOX we include a variable interacting the SOX variable with whether the CEO has financial expertise.

Change in performance and its elaboration. To test Hypothesis 4, we include a variable capturing change in performance, which is coded as the difference in the firm's industryadjusted return-on-assets in the two prior years. We include interactions between this variable and each of our three power indicators.

\section{Control Variables}

Alternative sources of board influence 
We include four separate variables to control for separate factors that might affect the CEO's relationship with other members of the board. First, we control for relative CEO tenure, measured as the ratio of the number of years the $\mathrm{CEO}$ has held their title divided by the average number of years that other directors have held their board seats. Second, we include a binary variable to control for firms in which the CEO is also the firm's founder, as founders may have a different relationship to board insiders than other CEOs. This is a binary variable that is coded " 1 " if the CEO founded the organization and "0" otherwise. And third, we include a control for CEO age, as CEOs approaching retirement may cede some decision-making control to other members of the board. Finally, to account for changes in a CEO's power concomitant with board structural changes, we include a binary control for change in duality, coded as "1" in any year in which a company that had had a separate Chairman gave its CEO that title.

Larger boards might have more "room" for both insiders and outsiders, potentially making it more difficult to adopt the CEO-only structure. Board size was calculated as the total number of board members. Additionally, we include a control for the percentage of insiders on the board. This variable, measured as the ratio of the number of insiders to the total number of board members, accounts for the difficulty of eliminating a large proportion of board members in one year. We also control for the number of insider departures at the firm, equal to the number of board insiders who left the company in the prior firm-year. This measure accommodates a host of voluntary and involuntary reasons that an insider may leave the firm - including, for example, herding behavior following a CEO succession - and thus accounts for sources of unobserved heterogeneity in changes to board structure. We also include a binary variable to indicate all boards with a classified board structure. A classified board is one where only a 
fraction of board members are up for renewal in any given year, preventing a wholesale departure of insiders.

The power of outsiders has been shown to constrain CEO behavior and improve the board's alignment with the interests of shareholders. However, outsiders also have a responsibility to provide advice and counsel to the CEO in decision making (Westphal, 1999) and may benefit in this endeavor from the presence of other insiders. Although we do not hypothesize an effect for outsider power, we suspect that these two competing interests -- that of monitoring and counsel -- could leave outsiders somewhat indifferent to structural change. We utilize two measures of outsider power. First, because outsiders who are recruited by the CEO may be less likely to stand up to the CEO than outsiders who predate the CEO, we include a control for the percentage of outsiders appointed by the CEO. Second, we include percentage of outsider stock ownership, coded as the number of shares held by the outside members of the board divided by the shares held by all board members.

Institutional investors are also a strong force in corporate governance (Davis \& Thompson, 1994; Useem, 1996). Institutional investors seek to increase outsider representation on the board (Johnson \& Greening, 1999), and is therefore likely that, institutional investors will support moves to eliminate insiders from the board. The influence and activism of institutional investors is likely to increase when they hold a substantial amount of a company's shares. Therefore, to estimate the impact of institutional investors on board structural change, we include a measure - blockholders -- that captures the total percentage of each firm's shares held by all institutional investors that hold a minimum of a 5\% block of the company's shares.

\section{Firm-specific controls}


We include controls for several firm-level explanations of board-structural change. We controlled for the level of performance using industry-adjusted return on assets (ROA) because it has been demonstrated to impact various dimensions of board changes (Shen \& Cannella, 2002). To control for the potential relationship between board structural change and managerial strategy and discretion, we include controls for firm size, in terms of logged assets and logged sales; firm age in years; resource availability in terms of cash on hand; and financial leverage in terms of debt-to-equity (Finkelstein \& D’Aveni 1994; Hambrick \& Finkelstein, 1987). We examined firm histories to account for previous CEO-only insider events, and recorded the number of times the CEO-insider only structure had been previously adopted at the firm. We also included a control for each firm's age, in years. And finally, we controlled for potential industry effects by including fixed effects for each SIC major industry division represented in the sample. Summary statistics and bivariate correlations of all dependent and independent variables are shown in Table 1, below.

[Insert Table 1 about here]

\section{Analysis and Results}

The analysis was conducted using a discrete-time event history analysis (Allison, 1984). Though directors may rarely be replaced due to death or unforeseen events at other times in a year, firms typically experience board changes once a year at their annual meeting when shareholders vote on a slate of directors. In light of this, our model uses calendar year as the time clock, with discrete time measures calculated for each calendar year. Given that firms typically experience board change at their annual meetings, all firms that change to the CEOonly structure in the same year are treated in the model as 'ties,' meaning that they are coded as 
experiencing the event at the same time, irrespective of when in the year they actually adopted the structure. This aspect of our data drove our decision to employ the discrete time event history model because it is capable of modeling ties, unlike continuous-time models -- such as the Cox model -- that are unable to handle multiple, co-occurring events (Arjas and Kangas, 1992; Yamaguchi, 1991). Given that some firms in our sample were at risk of transitioning to the CEO-only structure more than once (if they again brought in additional inside directors after two years of having the CEO-only structure), we treated the measure as a repeatable event (Boeker, 1992; Zajac and Wesphal, 1996).

The results of the event history analysis of changes in board structure are displayed in Table 2. We ran the models using both a simple probit and simple logit approach. We obtained similar results using both approaches, but the probit approach yielded a lower BIC statistic, suggesting that it was a better fit for our models. Thus, the results from the probit models are shown below.

[Insert Table 2 about here]

We tested our hypotheses using a series of nested models. Model 1 includes only control variables. Model 2 introduces the percentage of insiders appointed before the CEO in order to test hypothesis 1 . Model 3 tests hypothesis 2 by introducing variables to capture executive power. In model 4, we test hypothesis 3 by introducing the SOX variable and its interaction with CEOs with a finance background. Finally, in model 5 , we test hypothesis 4 by introducing the change in performance variable and its interactions with executive power.

The results for the control variables are consistent in each of the models. We do not find evidence that block-holding institutional investors have a significant effect on the adoption of the 
CEO-only structure. Of course, our findings do not preclude the possibility that institutional investors may push for greater board independence. They just may not work toward the "extreme" case of the CEO-only insider structure. We also find no effects for firm-level variables such as industry adjusted ROA, log of sales, firm age, debt-to-equity, or number of previous CEO-only events. We do find that board size is negatively associated with the event, suggesting that boards with more seats to fill are more likely to keep other insiders on the board. This is an especially interesting finding in light of larger trends toward shrinking board sizes. Figure 2 shows the average board size and insider/outsider ratio for the firms in our sample over the duration of the panel. As the figure suggests, board sizes decreased about $13 \%$ during the panel, but the average number of outsiders on boards remained fairly steady over this period. The trend toward smaller boards seems to be primarily explained by a near- $50 \%$ decrease in the average number of board insiders. Thus, whereas our results suggest that larger boards are less likely to have the CEO-only structure, if boards continue to shrink we would expect to see the structure continue to increase in prevalence.

[Insert Figure 2 about here]

We do not find evidence of any significant relationship between classified board structures and the event. The control for the percentage of insiders on the board was negative and significant, which suggests that when the board is populated by a large percentage of insiders, it may simply be too difficult to remove all of the insiders in a short period of time. However, the control for the number of insider departures is positive and significant, which suggests that insiders may leave in waves: once some insiders leave the board, it becomes more likely that the firm will remove all of its remaining insiders in the following year. 
We did not find any significant relationship between a CEO's tenure relative to the board and the structure. However, we do find that as CEOs age the CEO-only structure becomes less likely, perhaps due to the increased likelihood of the presence of an internal heir apparent. The control for the percentage of outsiders appointed by the CEO is positive and significant across models 2-5. CEOs may have more power over directors that have been awarded board seats under their watch, so this finding is consistent with our argument that powerful CEOs press for adoption of the CEO-only structure.

The control we included for change in $\mathrm{CEO} /$ Chairman duality was positive and significant across all models. This suggests that adoption of the CEO-only structure is more likely to occur along with a concomitant event that necessitates changing the structure of the board. Board members may be more open to adoption of the new structure when they are already involved in a task that requires changing the roles or members of the board. And finally, the number of firms that have adopted the CEO-only structure has a positive association with a firm's likelihood of adopting the structure that is near to significance in models 1,3 , and 5 . This provides some evidence that mimetic pressures encourage firms to adopt the CEO-only structure.

We now turn to our hypotheses. Overall, the results in models 2-5 provide strong support for hypothesis 1 , on CEO interests. Consistent with hypothesis 1 , boards with a larger percentage of inside directors who predate the $\mathrm{CEO}$ are more likely to adopt the CEO-only insider structure $(\mathrm{p}<.001)$. CEOs may not feel as advantaged by inside directors who they themselves did not propose to the board.

Hypothesis 2 receives support in models 3-5, for some determinants of CEO power, but not all. CEO duality has a positive and significant relationship with the adoption of the structure 
across models 3-5 $(\mathrm{p}<.01)$. We do not find evidence, however, that a CEO's relative share holdings or finance background has a significant main effect on the likelihood of the structure. The results indicate that the agenda control concomitant to duality may give these CEOs more leverage in altering board structure and composition, but other forms of CEO power do not have the same effects. For the case of finance CEOs, their power may be less than we hypothesized (cf., Ocasio \& Kim, 1999).

Hypotheses 3, involving Sarbanes Oxley and its elaboration by CEOs with finance backgrounds, received support in Models 4 and 5. As hypothesized, the interaction between SOX and CEO finance background is positive and significant $(\mathrm{p}<.05)$, indicating that the CEO-only structure was more likely after SOX in boards led by CEOs with financial expertise. SOX has a marginally significant negative association with the structures. The main effect of the CEO with a finance background is not significant, suggesting that SOX served as an elaboration opportunity for finance CEOs. The interaction effect is graphically demonstrated in Figure 3, below. The strongest predictor of adoption of the CEO-only structure is the percentage of insiders on the board in the prior year. There is a very low probability of the structure being adopted when the percentage of insiders is at its mean of roughly $25 \%$ of the board. However, as the proportion of insiders drops below the mean, the conditional probability of the CEO-only structure increases dramatically and the interactions we explore here become important predictors of when the structure is likely to occur. This suggests that the elaboration mechanisms we propose become most important when there are already relatively few insiders on the board. Thus, in the figure below, we have held the percentage of insiders at one standard deviation below the mean (roughly 13\%). All other control variables are held at their mean. As can be 
seen in the figure, the predicted likelihood of adoption of the CEO-only structure was similar (at around a $4 \%$ probability) regardless of whether a CEO had a finance background before SOX, but firms that have CEOs with finance backgrounds are about ten times more likely to adopt the structure after SOX than firms that have CEOs with no finance background.

\section{[Insert Figure 3 about here]}

We also receive support for hypothesis 4 , for two of the three measures of power, which suggests that powerful CEOs can leverage outperformance to press for adoption of the CEO-only structure. The main effect of change in performance is not significant, nor is its interaction with CEOs with a finance background. However, we do find significant and positive interactions between changes in performance and both CEO duality $(\mathrm{p}<.05)$ and CEOs' relative shareholdings $(\mathrm{p}<.01)$. These interactions are depicted in Figures 4 and 5, below. Again, the percentage of insiders is held at one standard deviation below the mean in these figures and all other controls are held at their mean. Figure 4 shows that firms with dual CEO/Chairman become more likely to adopt the structure as their change in performance improves, but those with a separate CEO and Chairman become less likely to adopt the structure as performance improves. Figure 5 suggests that for firms where industry-adjusted ROA has increased by 1 over the prior year, there is an almost $15 \%$ probability of the structure occurring in boards where CEOs hold $75 \%$ of the board's total shares, which is around four times more likely than in firms where the CEO holds $25 \%$ of the board's total shares.

[Insert Figures 4 and 5 about here]

\section{DISCUSSION}


In this paper, we explore the proliferation of a paradoxical phenomenon in corporate governance, the CEO-only board structure, where the CEO is the only insider on the board. The structure has spread without much notice or remark because it appears to neatly accord with the director independence mandate derived from agency theory and the logic of shareholder value. However, a growing body of evidence in management research and finance suggests that the CEO-only structure may in fact enhance the power and entrenchment of CEOs, leading to monitoring inefficiencies (Liu \& Jiraporn, 2008), increased managerial excess (Zorn, Shropshire, Martin \& Combs, 2013) and greater CEO influence (Adams et al, 2005). This evidence sparks our overarching research question: why do structures proliferate that appear to align with the objectives of a dominant institutional logic, but that work in practice to contravene those objectives?

To answer this question, we propose that the CEO-only structure exemplifies the phenomenon of structural elaboration, originally developed in the context of coercive institutional change, and extended here to apply to changes in institutional logics. Structural elaboration theory (Edelman, 1992) contends that organizations strategically respond to ambiguous institutional demands by adopting structures that appear to conform, but that work in reality to enhance executive interests. While the CEO-only structure is an elaborated form of board independence, a mandate derived from agency theory and the logic of shareholder value, we argue that the structure enhances the CEO's interests by proffering an information brokerage position and removing potential internal challengers.

Having identified the CEO-only structure as an example of structural elaboration, we explore the proliferation of the structure as an opportunity to construct and test a more precise 
theoretical model of the mechanisms that drive processes of structural elaboration: executive interests, executive power, and elaboration opportunities. Our basic premise is that CEO interests and power have a direct effect on what structural changes are made in response to pressures from new institutional logics. Specifically, we contend that the structures that proliferate in response to new logics will be consistent with the interests of powerful organizational executives, in our case the CEO. Executive power is not, however, monolithic, but is moderated by institutional events and organizational contingencies. In light of this, we propose that the timing of the adoption of new structures will be shaped by institutional events (like the passage of Sarbanes Oxley) or organizational contingencies (like increases in performance). Each of these examples of elaboration opportunities spark power mobilization and increase the likelihood that structures will be altered in ways that accord with the interests of powerful executives as well as the expectations of prevailing logics.

The present study has several limitations. First, our sample includes only the largest U.S. public corporations. Small, family-owned or otherwise private organizations may have different political dynamics, particularly when a founding family member is present. Second, given the many multi-divisional firms in our sample, finance backgrounds may be particularly important because of their usefulness in devising acquisition and diversification strategies (Song, 1982; Palmer \& Barber, 2001). Consequently, our indicators of financial expertise may be less applicable to other contexts. Third, like other large sample studies of boards of directors, this study does not directly observe the political processes by which power is exercised or mobilized (Pettigrew, 1992; Zajac \& Westphal, 1996). 
Our focus on the interests of powerful executives, in particular, highlights an important assumption in our model: that CEOs perceive CEO-only boards as being in their own selfinterest. Although we cannot directly test this relationship, as interests are inherently unobservable, it is a view shared by financial economists and organizational scholars that is informed by a growing body of empirical evidence that this structure advantages CEOs (e.g. Adams et al, 2005; Liu \& Jiraporn, 2008; Hoechle, Schmid, Walter\& Yermak, 2012; Zorn et al., 2013). Moreover, model-theoretic approaches to social inquiry suggest that constructs like "selfinterests" provide useful guidance on the nature of expected relationships even when they do not lead to directly testable hypotheses (Harris, Johnson and Souder, 2013). ${ }^{2}$ Indeed, the agency theoretic expectation that CEOs prefer to have insiders on their board because they expect insiders to be less diligent monitors has, to our knowledge, never been tested directly, but has been similarly employed as a springboard to testable hypotheses. Our assumption that CEOs prefer the CEO-only structure to alternate forms of independent-majority structures, which is grounded in a rich literature on socio-political processes on corporate boards (Zajac \& Westphal, 1996), recognizes that the proposed associations will not hold under all conditions (Tsang and Kwan, 1999), but still demonstrates an empirical regularity that informs and refines our scholarship on models of board structural change.

\footnotetext{
${ }^{2}$ Along these lines, realists in the philosophy of social science (e.g. Bhaskar, 1975; Godfrey and Hill, 1985) argue that testing theory for its veracity should not require the measurement of observable variables. Many "real" mechanisms are not directly observable but are, nevertheless, essential for understanding causal forces. In organizational and strategy research, examples include divergent interests in agency theory, tacit resources in the resource based view, and perceived opportunism in transaction costs economics.
} 
Our study offers several contributions to the literature. First, we extend structural elaboration theory to the domain of corporate governance, using the theory to explain why firms adopt governance structures that ostensibly accord with the expectations of a dominant institutional logic, but in actuality diverge from the logic's underlying principles. While Edelman applied structural elaboration to ambiguous changes in the law, we suggest that the theory can also be applied to understand organizational responses to ambiguous prescriptions of institutional logics. In so doing, we introduce structural elaboration as a lens to explain variation in the way institutional logics are instantiated inside organizations. Moreover, we augment structural elaboration theory by drawing from the socio-political perspective on corporate governance. Whereas Edelman's (1992) account focuses more on inter-organizational political dynamics, we focus on the intra-organizational political dynamics at the board level board that drive the elaboration of institutional logics. We argue and demonstrate that board structural change is shaped by the interest of powerful players in the organization (in particular, the CEO) as well as the opportunities to elaborate practices. By merging structural elaboration theory with the socio-political perspective, a breed of theoretical contribution Harris et al. (2013) recently referred to as "grafting," we are able to provide a more nuanced and precise theoretical model of how structural elaboration proceeds in practice.

We also add to the institutional logics literature by examining the role of structural elaboration in shaping the way institutional logics are realized inside organizations. Our focus on power, interests and opportunities as links between logics and agency, captures more fully how key organizational actors shape choices concerning the adoption and variation of practices and structures that reinforce existing logics. (Thornton et al, 2012). More generally, by focusing 
on the role of executive power and political opportunities undergirding structural elaboration, our theory answers the call for more attention to the micro-foundations of institutions (Thornton et al., 2012; Powell \& Colyvas, 2008; Zucker, 1991). Locally-constructed conceptions of institutions, such as Hallett \& Ventresca's (2006) theory of 'inhabited institutions' or Thornton et al's (2012) conception of negotiated order stress that institutions actually arise in the interaction between macro-level pressures and organization-level contingencies. These middle-range conceptions of institutions suggest that institutional myths are not merely handed down as rigid mandates or 'iron cages' (DiMaggio \& Powell, 1983), but are interpreted among actors seeking to appropriately respond to institutional expectations (Hallett, 2010). Our study augments this work and demonstrates the potential for practice variation and unintended contradictions between the underlying theoretical principles of agency theory and shareholder value maximization and the practices of the shareholder value logic. This incremental structural change has the potential to generate internal contradictions in the shareholder value logic, which could result in subsequent changes in the logic (Seo \& Creed, 2002). Our concept of elaboration opportunities is similar to what has previously been referred to as choice opportunities (March \& Olsen's, 1976), policy windows (Kingdon, 1984) and windows of opportunity (Tyre \& Orlikowski, 1994). It reflects a situated view of decision making which emphasizes the influence of situational characteristics on the critical issues and solutions that constitute the decision makers focus of attention (Ocasio, 1997). The concept of elaboration opportunity builds on related approaches by recognizing that opportunities for change are influenced simultaneously by institutional logics, decision-making situations and individual interests. Institutional and organizational events generate the attention of actors who have distinct preferences and 
capacities for influencing structural changes (Nigam \& Ocasio, 2010). Thus, structural change occurs in part because logics and more proximate influences provide social actors with impetus and motivation for elaboration and development of the extant logic.

At the same time, the concept of elaboration opportunity recognizes that power cannot be exerted under all conditions (March, 1966; Kingdon, 1984). Consequently, some elaboration opportunities offer better timing to assert a policy change than others. Since, the CEO's efforts to exert power are partly context dependent, the probability of the CEO's political activity increases with the presence of particular elaboration opportunities. The CEO, as an experienced political player (Vancil, 1987), will have a sense for whether the organizational context is favorable for political activity which supports their position and status.

This is consistent with the adoption patterns evident in our data. The adoption pattern of the CEO-only structure was uneven, and it was not marked by a watershed event. It evolved rather quietly and incrementally over time. Few firms (11) in our sample adopted the structure in the 1980s. Of those firms that had the structure at the start of our analysis - Coca-Cola, Conagra, Consolidated Freightways, Digital Equipment, Entergy, Northwest Airlines, Norwest and Weyerhauser - only Digital Equipment and Entergy had the structure at founding. Digital was led by its co-founder Kenneth Olsen and Entergy was controlled by utility regulators who could set the rate of return for shareholders and limit managerial discretion (Demsetz, 1983). Most firms (69) adopted the structure in the 1990s, including IBM, which serves as a canonical example of our model. At the time of the transition to a CEO-only board, Gerstner held both the Chair and CEO positions and owned 473,333 shares at the time of transition to CEO-only which was $93.6 \%$ of total shares held by board members. He was also only three years into his twelve- 
year tenure, but was leading a successful turnaround. Gerstner had control of the board agenda and his firm's superior performance provided an organizational opportunity to make changes.

This focus on opportunities may be a fruitful one for future researchers and additional work is needed to identify the role of decision opportunities in shaping power activation in other contexts and how they affect the elaboration of other structures and processes. Although not a focus of the present study, the historical trajectory of the CEO-only board structure does suggest that the individual agency of structural elaboration has the potential for change - or at least refinement - of the extant logic. More studies are needed to understand the role of elaboration in the development and transformation of institutional logics, and the endogenous process of institutional change more generally. In all, the elusive and recursive link between institutional and organizational change is an important one, and hopefully our study provides insights into one part of that process in articulating a concrete link between changes in the institutional environment and structural elaboration at the organizational level - of which board structure is but one example.

\section{CONCLUSION}

This paper explores the structural elaboration of organizational logics in the context of corporate governance. We began our paper by noting a paradox: the adoption of the CEO-only structure appears to conform to agency theory and shareholder value logics, but prior analyses of its empirical effects suggest that it works in practice to enrich and entrench the CEO, contrary to the shareholder value logic's ultimate objective. We resolve this paradox by finding evidence that while the principles of the shareholder value logic are apparently upheld by the adoption of 
the CEO-only structure, this structure in actuality is favored by powerful CEOs, and more so when it serves to remove insiders not explicitly beholden to the CEO for their board positions.

Our application of structural elaboration theory to corporate governance reminds us that institutional logics are inherently ambiguous, and that the application of their principles may not always serve their desired purposes, but instead serve the interests of powerful elites. Board independence is a taken-for-granted feature of the shareholder value logic, and supermajority outsider boards an established desiderata. Yet with the adoption of CEO-only boards, powerful CEOs embrace a structure that conforms to the principle of "board independence," albeit one that research has shown to facilitate the opposite, greater CEO entrenchment. 


\section{References}

Adams, R. B., Almeida, H., \& Ferreira, D. 2005. Powerful CEOs and their impact on corporate performance. Review of Financial Studies, 18(4): 1403-1432.

Adams, R.B., \& Ferreira, D. 2007. A theory of friendly boards. Journal of Finance, 61:217-250.

Allison, P.D. 1984. Event History Analysis. Newbury Park, CA: Sage.

American Law Institute. 1982. Principles of corporate governance and structure: Restatement and recommendations. Philadelphia, PA: American Law Institute.

Ansari, S. M., Fiss, P. C., \& Zajac, E. J. 2010. Made to fit: How practices vary as they diffuse. Academy of Management Review, 35(1): 67-92.

Argas, Elja and Pekka Kangas, 1992. A discrete-time method for the analysis of event histories. In Demographic Applications of Event History Analysis, ed. James Treussell, Richard Hankinson, and Judith Tilton. Oxford: Clarendon Press.

Ashforth, B. E. \& Gibbs, B.W. 1990. The double-edge of organizational legitimation. Organization Science. 1: 177-194.

Baysinger, B., \& Hoskisson, R. E. 1990. The composition of boards of directors and strategic control: Effects on corporate strategy. Academy of Management Review, 15: 72-87.

Bhagat, S., \& Black, B. 2001. The Non-Correlation between Board Independence and Long-Term Firm Performance. J. Corp. L., 27: 231.

Bigley, G., \& Wiersema, M. 2002. New CEOs and corporate strategic refocusing: How experience as heir apparent influences use of power. Administrative Science Quarterly, 47: 707-727.

Boeker, W. 1992. Power and managerial dismissal: Scapegoating at the top. Administrative Science Quarterly, 37: 400-421.

Boyd, B.K. 1995. CEO duality and firm performance: A contingency model. Strategic Management Journal, 16: 301-312.

Brickley, J.A., Coles J.L., \& Jarrell, G. 1997. Leadership structure: Separating the CEO and Chairman of the board. Journal of Corporate Finance, 3(3):189-220.

Burt, R.S. 1992. Structural holes: The social structure of competition. Cambridge, MA: Harvard University Press.

Cannella Jr., A.A., \& Shen, W.. 2001. So close and yet so far: Promotion versus exit for CEO heirs apparent. Academy of Management Journal, 44: 252-270.

Chhaochharia, V., \& Grinstein, Y. 2007. Corporate governance and firm value: The impact of the 2002 governance rules. Journal of Finance, 62(4):

Coates, J. C. 2007. The goals and promise of the Sarbanes-Oxley Act. The Journal of Economic Perspectives, 21(1): 91-116. 
Combs, J. G., Ketchen Jr., D. J., Perryman, A. A., \& Donahue, M. S. 2007. The moderating effect of CEO power on the board composition-firm performance relationship. Journal of Management Studies, 44: 1299-1323.

Cyert, R. M., and March, J. G.. 1963. A Behavioral Theory of the Firm. Englewood Cliffs, NJ: Prentice-Hall.

Daily, C. M., Dalton, D. R., \& Cannella, A. A. 2003. Corporate governance: decades of dialogue and data. Academy of Management Review, 28(3): 371-382.

Daily, C.M., \& Johnson J.L. 1997. Sources of CEO power and firm financial performance: A longitudinal assessment. Journal of Management, 23: 97-117.

Dalton, D. R., Daily, C. M., Ellstrand A. E., \& Johnson J. L., 1998. Meta-analytic reviews of board composition, leadership structure and financial performance. Strategic Management Journal, 19: 269-290.

Dalton, D., \& Kesner, I. 1987. Composition and CEO duality in boards of directors: An international perspective. Journal of International Business Studies, 18(3): 33-42.

David, P., Kochhar, R., \& Levitas, E. 1998. The effect of institutional investors on the level and mix of CEO compensation. Academy of Management Journal, 41: 200-208.

Davis, G. 1991. Agents without principles? The spread of the poison pill through the intercorporate network. Administrative Science Quarterly, 36: 583-613.

Davis, G. \& Stout, S. 1992. Organization theory and the market for corporate control, 1980-1990. Administrative Science Quarterly, 37: 605-633.

Davis, G., Diekmann, K.A., \& Tinsley, C. 1994. The decline and fall of the conglomerate firm in the 1980s: The deinstitutionalization of an organizational form. American Sociological Review, 59: 547-570.

Davis, G. 2009. Managed by the Markets: How Finance has Re-shaped America. New York: Oxford University Press.

Davis, G.F., Diekmann, K.A., \& Tinsley, C.H. 1994. The decline and fall of the conglomerate firm in the 1980s: The deinstitutionalization of an organizational form. American Sociological Review, 59: 547-570.

Davis, G.F., \& Thompson, T.A.. 1994. A social-movement perspective on corporate control. Administrative Science Quarterly, 39: 141-173.

Demsetz, H. 1983. The Structure of Ownership and the Theory of the Firm. JL \& Econ., 26: 375.

DiMaggio, P.J., \& Powell, W.W.. 1983. The iron cage revisited: Institutional isomorphism and collective rationality in organizational fields. American Sociological Review, 48:147-60.

Edelman, L.B. 1992. Legal ambiguity and symbolic structures: Organizational mediation of civil rights law. The American Journal of Sociology, 97:1531-1576.

Fama, E. 1980. Agency problems and the theory of the firm. Journal of Political Economics, 88:288-307.

Fama,E., \& Jensen, M. 1983. Separation of ownership and control. Journal of Law and Economics, 26: 301-326. 
Finkelstein, S. 1992. Power in top management teams: dimensions, measurement, and validation. Academy of Management Journal, 35(3): 505-538.

Finkelstein, S., \& D'Aveni, R.A.. 1994. CEO duality as a double-edged sword: How boards of directors balance entrenchment avoidance and unity of command. Academy of Management Journal, 37: 1079-1108.

Finkelstein, S., Hambrick, D.C., \& Cannella, A. A. 2009. Strategic leadership: Theory and research on executives, top management teams, and boards. New York: Oxford University Press.

Fiss, P.C., \& Zajac, E.J.. 2004. The diffusion of ideas over contested terrain: The (non)adoption of a shareholder value orientation among German firms. Administrative Science Quarterly, 49: 501-534.

Fiss, P.C., \& Zajac, E.J.. 2006. The symbolic management of strategic change: Sensegiving via framing and decoupling. Academy of Management Journal, 49:1173-1193.

Fligstein, N. 2001. The Architecture of Markets: An Economic Sociology of Twenty-First-Century Capitalist Societies. Princeton, NJ: Princeton University Press.

Fligstein, N. \& Markowitz, L. 1993. Financial reorganization of American coporations in the 1980s. In William J. Wilson (ed.) Sociology and the Public Agenda, 185-206.

Fligstein, N. \& Shin, T. Shareholder value and the transformation of the U.S. economy, 1984-2000. Sociological Forum, 22: 399-420.

Forbes, D. P., \& Milliken, F. J. 1999. Cognition and corporate governance: understanding boards of directors as strategic decision-making groups. Academy of Management Review, 24(3): 489-505.

Friedland, R., \& Alford, R. R. 1991. Bringing society back in: Symbols, practices and institutional contradictions.

Froot, K.A., Scharfstein, D.S., \& Stein, J.C. 1992. Herd on the street: Informational inefficiencies in a market with short-term speculation. Journal of Finance, 47: 1461-1484.

Gerstner, L. V. 2002. Who says elephants can't dance?: Inside IBM's historic turnaround. HarperBusiness: 75-76.

Godfrey, P.C., \& Hill, C.W.L. 1995. The problem of unobservables in strategic management research. Strategic Management Journal, 16: 519-533.

Goldstein, A. 2012. Revenge of the managers: Labor cost-cutting and the paradoxical resurgence of managerialism in the shareholder value era, 1984 to 2001. American Sociological Review, 77: 268-294.

Gordon, J. N. 2007. The rise of the independent directors in the United States, 1950-2005: Of shareholder value and stock market prices. Stanford Law Review, 59: 1465-1568.

Green Jr., S. E., Babb, M., \& Alpaslan, C. M. 2008. Institutional Field Dynamics and the Competition Between Institutional Logics The Role of Rhetoric in the Evolving Control of the Modern Corporation. Management Communication Quarterly, 22(1): 40-73.

Greenwood, R., \& Suddaby, R. 2006. Institutional Entrepreneurship in Mature Fields: The Big Five Accounting Firms. Academy of Management Journal, 49(1): 27-48. 
Haleblian, J., \& Finkelstein, S.. 1993. Top management team size, CEO dominance, and firm performance: The moderating roles of environmental turbulence and discretion. Academy of Management Journal, 36: 844863 .

Hallett, T. 2010. The myth incarnate: Recoupling processes, turmoil, and inhabited institutions in an urban elementary school. American Sociological Review, 75:52-74.

Hallett, T., \& Ventresca, M.. 2006. Inhabited institutions: Social interactions and organizational forms in Gouldner's 'Patterns of Institutional Bureaucracy'. Theory and Society, 35: 213-236.

Hambrick, D. C., \& Finkelstein, S. (1987). Managerial discretion: A bridge between polar views of organizational outcomes. Research in Organizational Behavior.

Harris, M., \& Raviv, A. 2008. A theory of board control and size. Review of Financial Studies, 21(4): 1797-1832.

Hartzell, J.C., \& Starks, L.T.. 2003. Institutional investors and executive compensation. The Journal of Finance, 58: 2351-2374.

Hermalin, B. E., \& Weisbach, M. S. 1988. The determinants of board composition. Rand Journal of Economics, 19: 589-606.

Hermalin, B. E., \& Weisbach, M. S. 1998. Endogenously chosen boards of directors and their monitoring of the CEO. American Economic Review, 88: 96-118.

Hermalin, B. E., \& Weisbach, M. S. 2003. Boards of directors as an endogenously determined institution: A survey of the economic literature. Economic Policy Review, 9: 7-26.

Hickson, D. J., Hinings, C. R., Lee, C. A., Schneck, R. E., \& Pennings, J. M. 1971. A strategic contingencies' theory of intraorganizational power. Administrative Science Quarterly, 216-229.

Hoechle, D., Schmid, M., Walter, I., \& Yermack, D. 2012. How much of the diversification discount can be explained by poor corporate governance?. Journal of Financial Economics, 103(1): 41-60.

Jacobs, M.T. 1991. Short-term America: The causes and cures of our business myopia. Boston: Harvard Business School Press.

Jensen, M. 1993. The modern industrial revolution, Exit and the failure of internal control systems. Journal of Financial Economics,

Jensen, M. C., \& Meckling, W. H. 1976. Theory of the firm: Managerial behavior, agency costs and ownership structure. Journal of Financial Economics, 3(4): 305-360.

Johnson, R.A., \& Greening, D.W.. 1999. The effects of corporate governance and institutional ownership types on corporate social performance. Academy of Management Journal, 42: 564-576.

Johnson, S. G., Schnatterly, K., \& Hill, A. D. 2013. Board Composition Beyond Independence Social Capital, Human Capital, and Demographics. Journal of Management, 39(1): 232-262.

Kalev, A., \& Dobbin, F. 2006. Enforcement of civil rights law in private workplaces: The effects of compliance reviews and lawsuits over time. Law \& Social Inquiry, 31(4): 855-903. 
Kellogg, K.C. 2009. Operating room: Relational spaces and microinstitutional change in surgery. American Journal of Sociology, 115: 657-711.

Kim, Y., \& Cannella, A. A. 2008. Toward a social capital theory of director selection. Corporate Governance: An International Review, 16(4): 282-293.

Kingdon, J. W. 1984. Agendas, alternatives and public policies. Boston: Little, Brown.

Kmec, J. A., \& Skaggs, S. L. 2009. Organizational Variation in Formal Equal Employment Opportunity Structures. Sociological Forum, 24(1): 47-75.

Kochhar, R., \& David, P. 1996. Institutional investors and firm innovation: A test of competing hypotheses. Strategic Management Journal, 17: 73-84.

Jiraporn, P., \& Liu, Y. 2008. Staggered boards, capital structure, and firm value. Financial Analysts Journal, 64: 49-61.

Lok, J. 2010. Institutional logics as identity projects. Academy of Management Journal, 53(6): 1305-1335.

Lounsbury, M. 2001. Institutional sources of practice variation: Staffing college and university recycling programs. Administrative Science Quarterly, 46(1): 29-56.

Lounsbury, M. 2007. A Tale of Two Cities: Competing Logics and Practice Variation in the Professionalizing of Mutual Funds. Academy of Management Journal, 50(2): 289-307.

Lounsbury, M. 2008. Institutional rationality and practice variation: New directions in the institutional analysis of practice. Accounting, Organizations and Society, 33(4): 349-361.

Lynall, M. D., Golden, B. R., \& Hillman, A. J. 2003. Board composition from adolescence to maturity: a multitheoretic view. Academy of Management Review, 28(3): 416-431.

Main, B. G., O'Reilly, C. A., \& Wade, J. 1995. The CEO, the board of directors and executive compensation: Economic and psychological perspectives. Industrial and Corporate Change, 4(2): 293-332.

March, J.G. 1966. The power of power. In Easton, D. (ed.) Varieties of Political Theory: 39-70. New York, NY: Prentice-Hall.

March, J.G., \& Olsen, J.P. 1976. Ambiguity and Choice in Organizations. Bergen: Universitetsforlaget.

Marquis, C., \& Lounsbury, M. 2007. Vive la resistance: Consolidation and community-level professional countermobilization in US banking. Academy of Management Journal, 50(4): 799-820.

Matsunaga, S., \& Yeung, E. 2008. Evidence on the impact of a CEO's financial experience on the quality of the firm's financial reports and disclosures.

Meyer, R. E., \& Hammerschmid, G. 2006. Changing Institutional Logics and Executive Identities: A Managerial Challenge to Public Administration in Austria. American Behavioral Scientist, 49(7): 1000-1014.

Meyer, A. D. 1982. Adapting to environmental jolts. Administrative Science Quarterly, 515-537.

Mitchell, L. E. 2004. Structural Holes, CEOs, and Informational Monopolies-The Missing Link in Corporate Governance. Brook. L. Rev., 70: 1313. 
Mizruchi, M. S. 1983. Who controls whom? An examination of the relation between management and boards of directors in large American corporations. Academy of Management Review, 426-435.

Morck, R. 2004. Behavioral finance in corporate governance - Independent directors and non-executive chairs." NBER Working Paper, No. W10644.

Nigam, A., \& Ocasio, W. 2010. Event attention, environmental sensemaking, and change in institutional logics: An inductive analysis of the effects of public attention to Clinton's health care reform initiative. Organization Science, 21(4): 823-841.

Ocasio, W. 1994. Political Dynamics and the Circulation of Power: CEO Succession in U.S. Industrial Corporations, 1960-1990. Administrative Science Quarterly, 39: 285-312.

Ocasio, W. 1997. Towards an attention-based view of the firm. Strategic Management Journal, 18(S1), 187-206.

Palmer, D., \& Barber, B.M.. 2001. Challengers, elites, and owning families: A social class theory of corporate acquisitions in the 1960s. Administrative Science Quarterly, 46: 87-120.

Pettigrew, A.M. 1992. On studying managerial elites. Strategic Management Journal, 13: 163-182.

Pfeffer, J. 1981. Management as symbolic action: The creation and maintenance of organizational paradigms. In L.L. Cummings and B.M. Staw (Eds.), Research in Organizational Behavior, vol. 3:1-52. Greenwich, CT: JAI Press.

Porac, J.F., Wade, J.B., \& Pollock, T.G. 1999. Industry categories and the politics of the comparable firm in CEO compensation. Administrative Science Quarterly, 44:112-144.

Powell, W.W., \& Colyvas, J.A.. 2008. Microfoundations of institutional theory. In R. Greenwood, C. Oliver, K. Sahlin-Andersson, and R. Suddaby, eds. Organizational Institutionalism, 276-298.

Reay, T., \& Hinings, C. R. 2009. Managing the rivalry of competing institutional logics. Organization Studies, 30(6): 629-652.

Rechner, P.L. \& Dalton, D.R. 1991. CEO duality and organizational performance: A longitudinal analysis. Strategic Management Journal, 33: 834-859.

Rosenstein, S., \& Wyatt, J. G. 1990. Outside directors, board independence, and shareholder wealth. Journal of Financial Economics, 26(2): 175-191.

Seo, M. G., \& Creed, W. D. 2002. Institutional contradictions, praxis, and institutional change: A dialectical perspective. Academy of Management Review, 222-247.

Shen, W., \& Cannella, A.A. 2002. Power dynamics within top management and their impacts on CEO dismissal followed by inside succession. Academy of Management Journal, 45:1195-1206.

Shipilov, A. V., Greve, H. R., \& Rowley, T. J. 2010. When do interlocks matter? Institutional logics and the diffusion of multiple corporate governance practices. Academy of Management Journal, 53(4): 846-864.

Song, J.H. 1982. Diversification strategies and the experience of top executives of large firms. Strategic Management Journal, 3: 377-380. 
Sonnenfeld, J. 2004. Good governance and the misleading myths of bad metrics. The Academy of Management Executive (1993-2005), 18(1): 108-113.

Spencer Stuart. 2011. Board Index: Board Trends and Practices at S\&P Corporations.

Thornton, P. H., \& Ocasio, W. 1999. Institutional logics and the historical contingency of power in organizations: Executive succession in the higher education publishing industry, 1958-1990. American Journal of Sociology, 105(3): 801-843.

Thornton, P.H., \& Ocasio, W. 2008. Institutional logics. In R. Greenwood, C. Oliver, K. Sahlin-Andersson, and R. Suddaby (eds), Handbook of organizational institutionalism. Thousand Oaks, CA: Sage.

Thornton, P. H., Ocasio, W., \& Lounsbury, M. 2012. The institutional logics perspective: A new approach to culture, structure, and process. OUP Oxford.

Tyre, M. J., \& Orlikowski, W. J. 1994. Windows of opportunity: Temporal patterns of technological adaptation in organizations. Organization Science, 5(1): 98-118.

Useem, M. 1993. Executive Defense: Shareholder Power and Corporate Reorganization. Cambridge, MA: Harvard University Press.

Useem, M. 1996. Investor Capitalism: How Money Managers are Changing the Face of Corporate America. New York: Basic Books/HarperCollins.

Vancil, R.F. 1987. Passing the Baton: Managing the Process of CEO Succession. Boston, MA: Harvard Business School Press.

Wade, J.B., Porac, J.F., \& Pollock, T.G.. 1997. Worth, words, and the justification of executive pay. Journal of Organizational Behavior, 18(supplement1): 641-664.

Westphal, J.D. 1998. Board games: How CEOs adapt to increases in structural board independence from management. Administrative Science Quarterly, 43: 511-537.

Westphal, J.D. 1999. Collaboration in the boardroom: the consequences of social ties in the CEO/board relationship. Academy of Management Journal, 42: 7-24

Westphal, J. D., \& Graebner, M. E. 2010. A matter of appearances: How corporate leaders manage the impressions of financial analysts about the conduct of their boards. Academy of Management Journal, 53(1): 15-44.

Westphal, J. D., \& Khanna, P. 2003. Keeping directors in line: Social distancing as a control mechanism in the corporate elite. Administrative Science Quarterly, 48(3): 361-398.

Westphal, J.D., \& Zajac, E.J. 1994. Substance and symbolism in CEOs' long-term incentive plans. Administrative Science Quarterly, 39: 367-390.

Westphal, J.D., \& Zajac, E.J.. 1995. Who shall govern? CEO/board power, demographic similarity, and new director selection. Administrative Science Quarterly, 40: 60-83.

Westphal, J. D., \& Zajac, E. J. 1997. Defections from the inner circle: Social exchange, reciprocity, and the diffusion of board independence in US corporations. Administrative Science Quarterly, 161-183. 
Winter Jr., R. K. 1977. State law, shareholder protection, and the theory of the corporation. J. Legal Stud., 6: 251.

Zajac, E. J., Kraatz, M. S., \& Bresser, R. K. 2000. Modeling the dynamics of strategic fit: A normative approach to strategic change. Strategic Management Journal, 21(4): 429-453.

Zajac, E.J., \& Westphal, J.D. 1995. Accounting for the explanations of CEO compensation: Substance and symbolism. Administrative Science Quarterly, 40: 283-308.

Zajac, E.J., \& Westphal, J.D. 1996. Director reputation, CEO-board power, and the dynamics of board interlocks. Administrative Science Quarterly, 41:507-529.

Zald, M. 1969. The power and functions of boards and directors: A theoretical synthesis. American Journal of Sociology, 75: 97-111.

Zorn, D., Dobbin, F., Dierkes, J., \& Kwok, M-S. 2005. Managing investors: How financial markets reshaped the American firm. In K. Knoor Cetina and A. Preda (eds.) The Sociology of Financial Markets, 269-289.

Zucker, L.G. 1991. Postscript: Microfoundations of Institutional Thought. In W. Powell and P. DiMaggio (eds.) The New Institutionalism in Organizational Analysis, 103-167. 
Figure 1. Percentage of sample with CEO-only structure

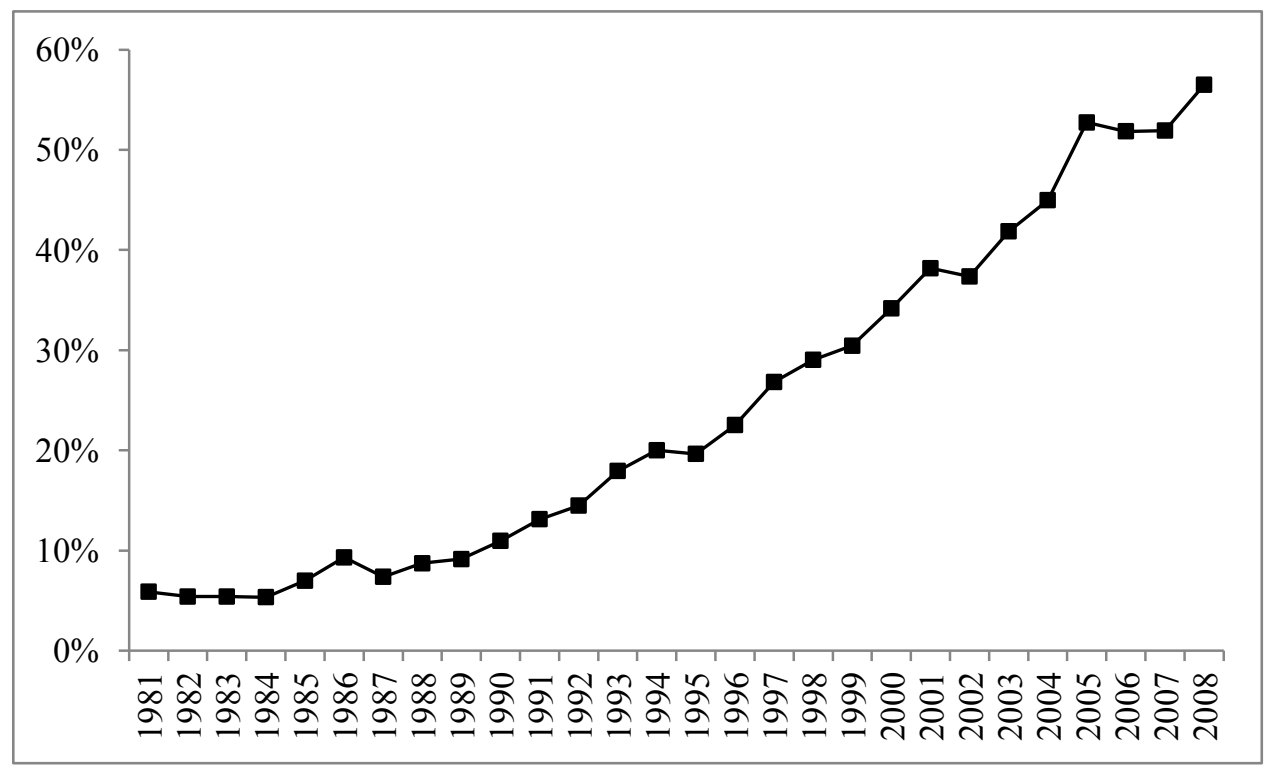

Figure 2. Changes in board structure: 1981 - 2008

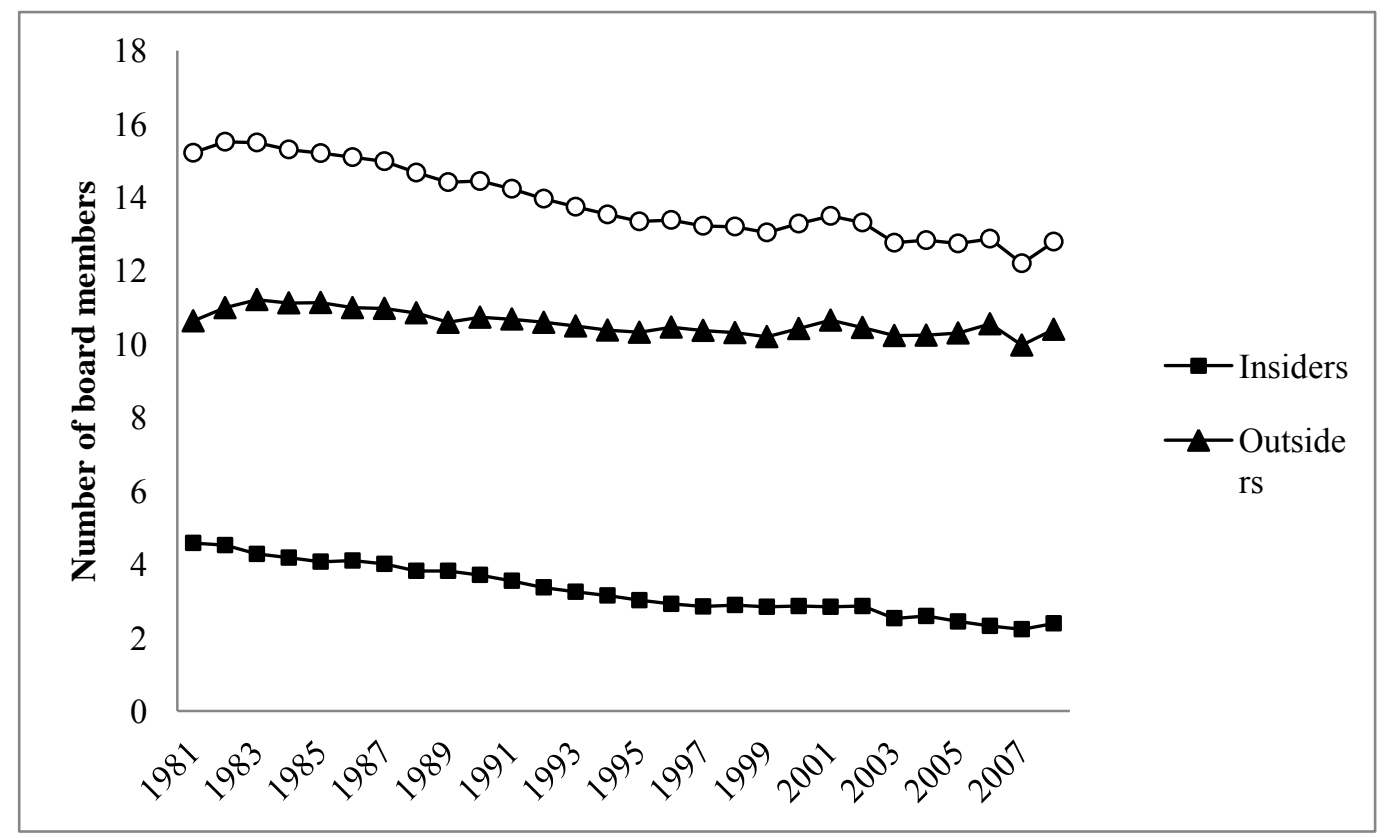


Figure 3. Predicted Probability of the CEO-Only Structure, Demonstrating the Interaction of Sarbanes Oxley and CEOs with a Finance Background

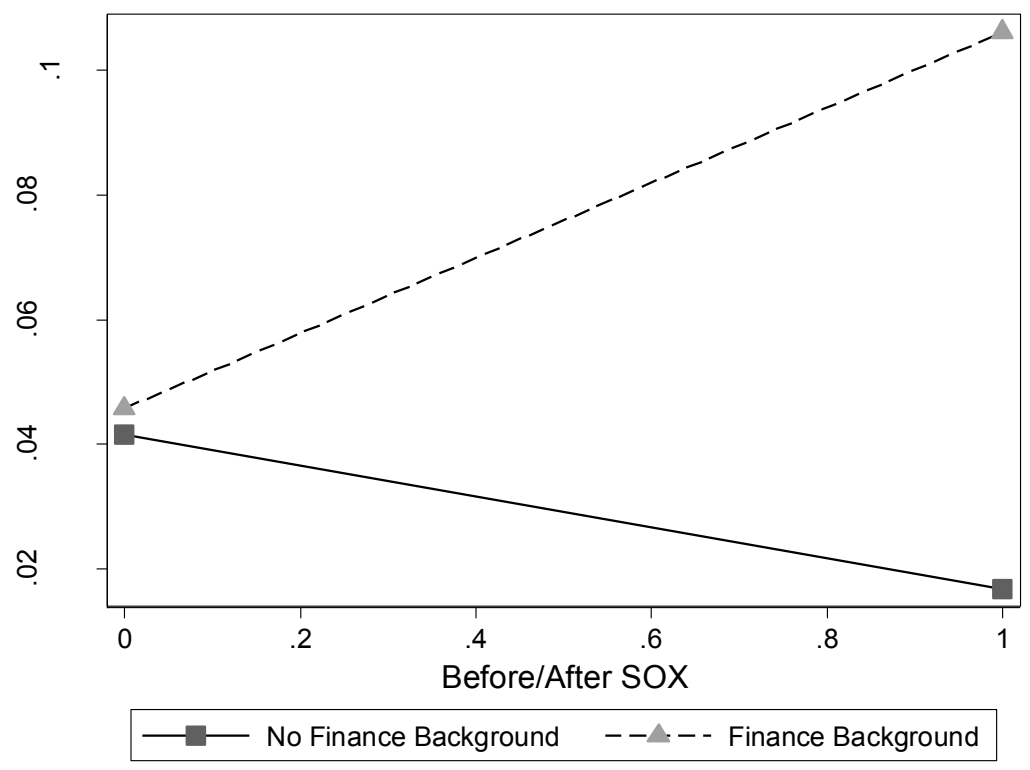

Figure 4. Predicted Probability of the CEO-Only Structure, Demonstrating the Interaction of Change in Performance and CEO Duality

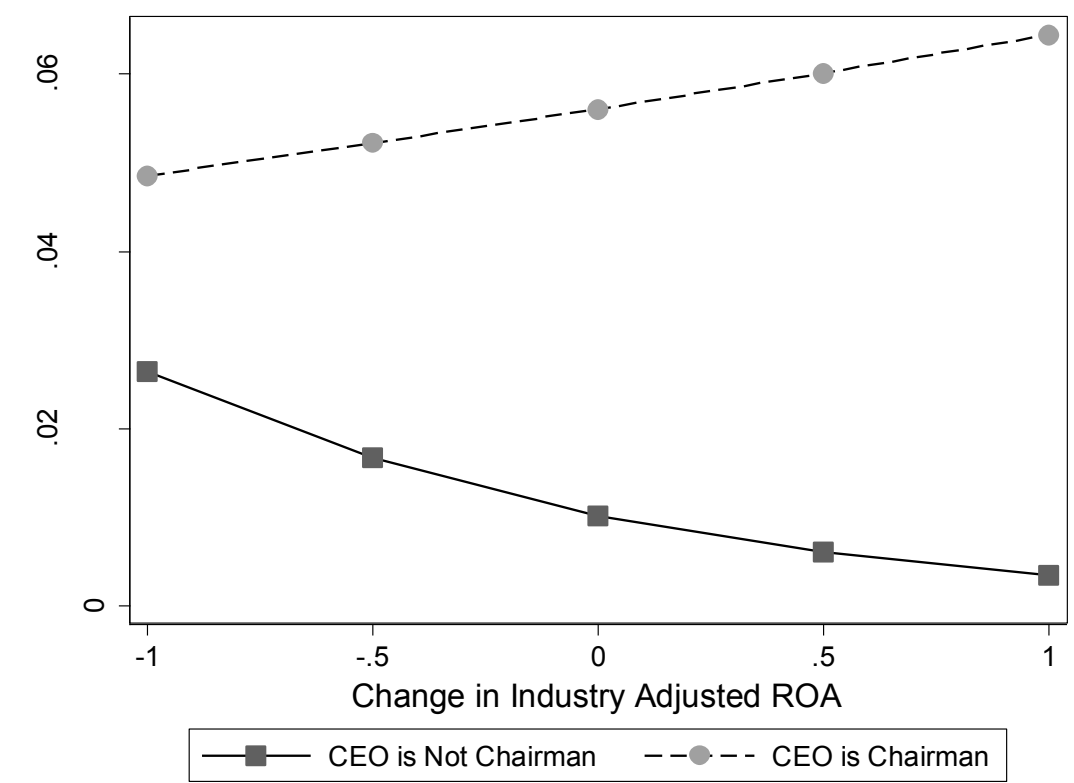


Figure 5. Predicted Probability of the CEO-Only Structure, Demonstrating the Interaction of Change in Performance and CEO's Relative Shares

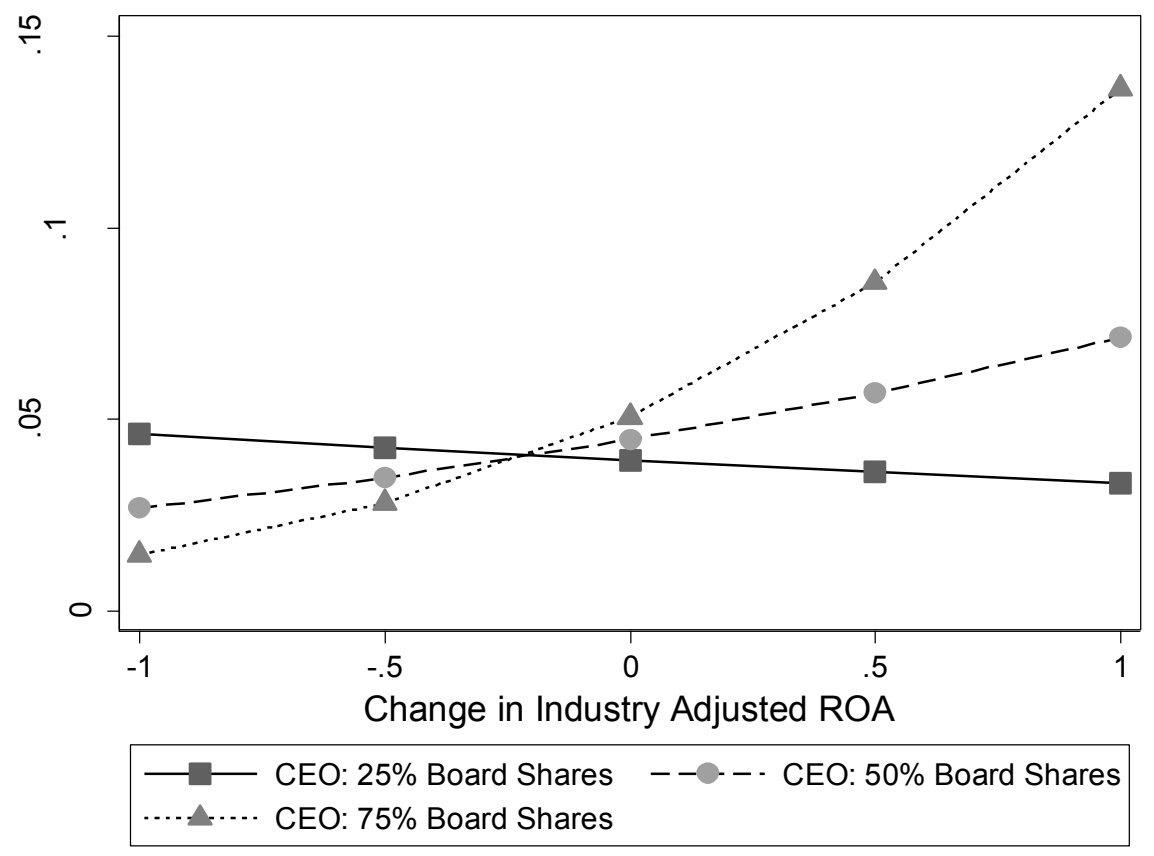


Table 1: Descriptive Statistics and Correlation Table

\begin{tabular}{|c|c|c|c|c|c|c|c|c|c|}
\hline Name & Mean & S.D. & Min & Max & 1 & 2 & 3 & 4 & 5 \\
\hline 1 CEO-Only Event & 0.043 & 0.20 & 0.00 & 1.00 & 1.000 & & & & \\
\hline 2 CEO Duality & 0.781 & 0.41 & 0.00 & 1.00 & -0.080 & 1.000 & & & \\
\hline 3 CEO Relative Shares & 0.263 & 0.28 & 0.00 & 1.00 & 0.064 & 0.143 & 1.000 & & \\
\hline $4 \mathrm{CEO}$ is Founder & 0.042 & 0.20 & 0.00 & 1.00 & -0.009 & 0.034 & 0.197 & 1.000 & \\
\hline 5 CEO Finance Background & 0.238 & 0.43 & 0.00 & 1.00 & 0.021 & -0.040 & -0.028 & -0.059 & $\begin{array}{ll}9 & 1.000\end{array}$ \\
\hline $6 \%$ Insiders Predating CEO & 0.638 & 0.42 & 0.00 & 1.00 & 0.163 & -0.221 & -0.178 & -0.195 & $5-0.020$ \\
\hline 7 Sarbanes Oxley & 0.099 & 0.30 & 0.00 & 1.00 & 0.103 & -0.123 & 0.067 & -0.048 & -0.026 \\
\hline 8 Change in Performance & 0.005 & 0.66 & -9.51 & 9.09 & 0.041 & -0.009 & 0.008 & -0.005 & 50.016 \\
\hline 9 CEO Relative Tenure & 0.859 & 0.87 & 0.00 & 6.46 & -0.065 & 0.227 & 0.192 & 0.267 & $7 \quad 0.000$ \\
\hline $10 \%$ Outsiders Appt. by CEO & 0.376 & 0.35 & 0.00 & 1.00 & -0.072 & 0.229 & 0.213 & 0.261 & -0.003 \\
\hline 11 CEO Age & 56.682 & 6.60 & 33.00 & 92.00 & -0.075 & 0.214 & 0.084 & -0.005 & 50.003 \\
\hline 12 Logged Assets & 9.358 & 1.40 & 4.22 & 14.60 & 0.059 & 0.014 & -0.027 & -0.193 & 30.288 \\
\hline $13 \%$ Board Shares Held by Outsiders & 0.307 & 0.32 & 0.00 & 1.00 & 0.005 & -0.037 & -0.367 & -0.132 & 20.047 \\
\hline 14 Cash & 1223.876 & 3291.44 & -150.17 & 40412.00 & 0.053 & -0.017 & -0.010 & -0.065 & 50.208 \\
\hline 15 DebttoEquity & 6769.244 & 28169.98 & 0.00 & 486876.00 & 0.018 & -0.012 & -0.001 & -0.043 & 30.056 \\
\hline 16 Classified Board & 0.528 & 0.50 & 0.00 & 1.00 & 0.000 & 0.071 & 0.043 & 0.035 & -0.087 \\
\hline 17 Board Size & 14.133 & 3.91 & 2.00 & 43.00 & -0.078 & 0.077 & -0.187 & -0.145 & 50.210 \\
\hline 18 Percentage Insiders on Board & 0.259 & 0.12 & 0.07 & 1.00 & -0.124 & -0.166 & -0.070 & 0.117 & $7-0.115$ \\
\hline 19 Change in Duality & 0.059 & 0.23 & 0.00 & 1.00 & 0.231 & -0.486 & -0.069 & -0.025 & $5-0.008$ \\
\hline 20 Insider Departures & 0.108 & 0.39 & 0.00 & 5.00 & 0.063 & -0.005 & -0.007 & -0.003 & $3-0.028$ \\
\hline 21 \# Other Firms with Structure & 39.692 & 22.82 & 11.00 & 87.00 & 0.157 & -0.130 & 0.133 & -0.099 & -0.032 \\
\hline 22 Industry Adjusted ROA & 0.168 & 0.57 & -3.46 & 9.56 & 0.047 & -0.036 & 0.029 & -0.018 & $3-0.069$ \\
\hline 23 Logged Sales & 9.105 & 0.99 & 2.52 & 12.75 & 0.057 & 0.006 & 0.010 & -0.217 & $7-0.008$ \\
\hline 24 Firm Age & 77.221 & 42.43 & -15.00 & 197.00 & 0.040 & 0.088 & -0.016 & -0.261 & 10.072 \\
\hline 25 Prior CEO-Only Events & 0.096 & 0.32 & 0.00 & 3.00 & 0.116 & -0.068 & 0.029 & -0.063 & 30.006 \\
\hline 26 Blockholders & 2.452 & 8.00 & 0.00 & 99.72 & 0.036 & -0.046 & 0.020 & -0.024 & +-0.005 \\
\hline
\end{tabular}

Table continued on next page 


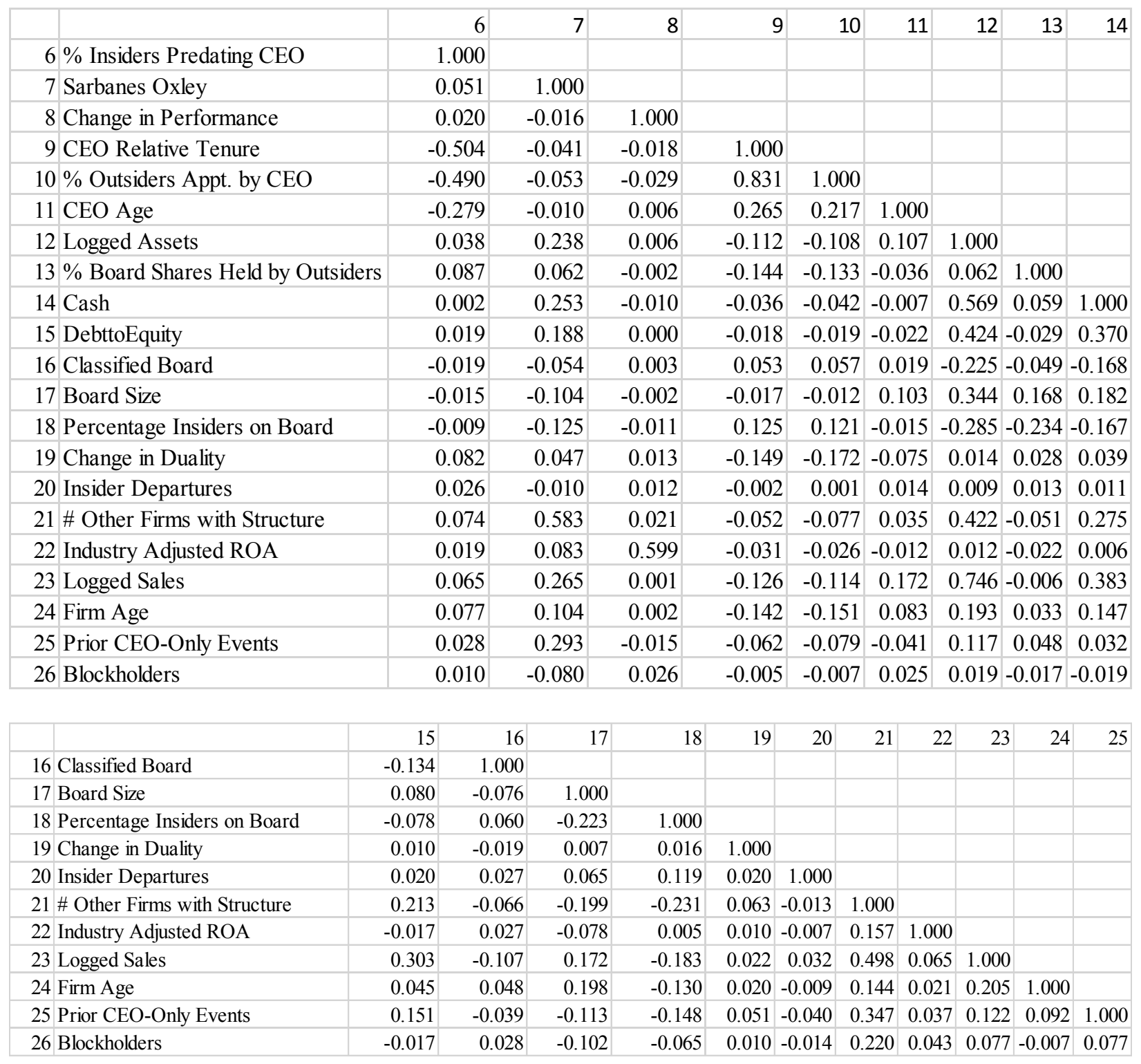


Table 2. Discrete Time Event History Analysis of the Likelihood of Adoption of the CEOonly Structure

\begin{tabular}{|c|c|c|c|c|c|}
\hline & Model 1 & Model 2 & Model 3 & Model 4 & Model 5 \\
\hline \multirow[t]{2}{*}{ \% Insiders Pre dating the CEO } & & $1.871 * * *$ & $1.994 * * *$ & $2.024 * * *$ & $2.055 * * *$ \\
\hline & & $(0.33)$ & $(0.36)$ & $(0.37)$ & $(0.39)$ \\
\hline \multirow[t]{2}{*}{ CEO Duality } & & & $0.828 * * *$ & $0.770 * *$ & $0.741 * *$ \\
\hline & & & $(0.23)$ & $(0.24)$ & $(0.23)$ \\
\hline \multirow[t]{2}{*}{ CEO Relative Shares } & & & 0.311 & 0.297 & 0.256 \\
\hline & & & $(0.27)$ & $(0.28)$ & $(0.28)$ \\
\hline \multirow[t]{2}{*}{ CEO is Founder } & & & 0.275 & 0.278 & 0.324 \\
\hline & & & $(0.42)$ & $(0.43)$ & $(0.43)$ \\
\hline \multirow[t]{2}{*}{ CEO Finance Background } & & & 0.23 & 0.0447 & 0.0511 \\
\hline & & & $(0.16)$ & $(0.19)$ & $(0.19)$ \\
\hline \multirow[t]{2}{*}{ Sarbanes Oxley (SOX) } & & & & $-0.391+$ & $-0.418+$ \\
\hline & & & & $(0.23)$ & $(0.24)$ \\
\hline \multirow[t]{2}{*}{ SOX $x$ Finance Background } & & & & $0.859 *$ & $0.838^{*}$ \\
\hline & & & & $(0.37)$ & $(0.39)$ \\
\hline \multirow[t]{2}{*}{$\Delta$ Performance } & & & & & $-0.391 * *$ \\
\hline & & & & & $(0.14)$ \\
\hline \multirow[t]{2}{*}{$\Delta$ Perf. x Duality } & & & & & $0.510^{*}$ \\
\hline & & & & & $(0.22)$ \\
\hline \multirow[t]{2}{*}{$\Delta$ Perf. $x$ Relative Shares } & & & & & $1.133 * *$ \\
\hline & & & & & $(0.38)$ \\
\hline \multirow[t]{2}{*}{$\Delta$ Perf. $x$ Founder } & & & & & -0.584 \\
\hline & & & & & $(0.42)$ \\
\hline \multirow[t]{2}{*}{$\Delta$ Perf. $x$ Fin. Background } & & & & & 0.159 \\
\hline & & & & & $(0.17)$ \\
\hline \multicolumn{6}{|l|}{ Controls } \\
\hline \multirow[t]{2}{*}{ CEO Relative Tenure } & -0.325 & 0.243 & 0.122 & 0.0991 & 0.0855 \\
\hline & $(0.20)$ & $(0.20)$ & $(0.23)$ & $(0.23)$ & $(0.23)$ \\
\hline \% Outsiders Appointed & 0.625 & 0.696 & $0.802+$ & $0.889 *$ & $0.972 *$ \\
\hline ВУ CEO & $(0.41)$ & $(0.42)$ & $(0.44)$ & $(0.44)$ & $(0.45)$ \\
\hline \multirow[t]{2}{*}{ CEO Age } & $-0.0319 * *$ & $-0.0383 * *$ & $-0.0428 * * *$ & $-0.0412 * *$ & $-0.0432 * * *$ \\
\hline & $(0.01)$ & $(0.01)$ & $(0.01)$ & $(0.01)$ & $(0.01)$ \\
\hline \multirow[t]{2}{*}{ Logged Assets } & 0.137 & 0.0585 & 0.0596 & 0.0651 & 0.131 \\
\hline & $(0.12)$ & $(0.15)$ & $(0.15)$ & $(0.15)$ & $(0.16)$ \\
\hline \% Board Shares Held by & $-0.308+$ & $-0.516^{*}$ & -0.359 & -0.377 & -0.358 \\
\hline Outsiders & $(0.19)$ & $(0.20)$ & $(0.23)$ & $(0.23)$ & $(0.24)$ \\
\hline
\end{tabular}


Table 2. Discrete Time Event History Analysis of the Likelihood of Adoption of the CEOonly Structure (cont'd)

\begin{tabular}{|c|c|c|c|c|c|}
\hline \multirow[t]{2}{*}{ Cash } & 1.61E-05 & 2.77E-05 & 3.37E-05* & 3.76E-05* & 3.84E-05* \\
\hline & $(0.00)$ & $(0.00)$ & $(0.00)$ & $(0.00)$ & $(0.00)$ \\
\hline \multirow[t]{2}{*}{ DebttoEquity } & $-2.22 \mathrm{E}-06$ & $-3.00 E-06$ & $-1.90 \mathrm{E}-06$ & $-2.14 E-06$ & $-2.73 E-06$ \\
\hline & $(0.00)$ & $(0.00)$ & $(0.00)$ & $(0.00)$ & $(0.00)$ \\
\hline \multirow[t]{2}{*}{ Classified Board } & 0.182 & 0.202 & 0.231 & 0.209 & 0.191 \\
\hline & $(0.12)$ & $(0.14)$ & $(0.14)$ & $(0.14)$ & $(0.14)$ \\
\hline \multirow[t]{2}{*}{ Board Size } & $-0.244 * * *$ & $-0.239 * * *$ & $-0.231 * * *$ & $-0.230 * * *$ & $-0.240 * * *$ \\
\hline & $(0.04)$ & $(0.05)$ & $(0.05)$ & $(0.05)$ & $(0.05)$ \\
\hline \multirow[t]{2}{*}{$\%$ Insiders on Board } & $-14.78 * * *$ & $-15.61 * * *$ & $-15.57 * * *$ & $-15.58 * * *$ & $-16.21 * * *$ \\
\hline & $(2.41)$ & $(2.67)$ & $(2.81)$ & $(2.80)$ & $(2.42)$ \\
\hline \multirow[t]{2}{*}{ Change in Duality } & $1.755 * * *$ & $1.965 * * *$ & $2.660 * * *$ & $2.610 * * *$ & $2.629 * * *$ \\
\hline & $(0.17)$ & $(0.20)$ & $(0.29)$ & $(0.29)$ & $(0.29)$ \\
\hline \multirow[t]{2}{*}{ \# Board Departures } & $0.895 * * *$ & $0.949 * * *$ & $0.930 * * *$ & $0.948 * * *$ & $0.999 * * *$ \\
\hline & $(0.14)$ & $(0.14)$ & $(0.15)$ & $(0.15)$ & $(0.14)$ \\
\hline \# Other Companies with & 0.00600 & 0.00570 & $0.00738+$ & 0.00795 & $0.00859+$ \\
\hline CEO-Only Structure & $(0.00)$ & $(0.00)$ & $(0.00)$ & $(0.00)$ & $(0.01)$ \\
\hline \multirow[t]{2}{*}{ Industry Adjusted ROA } & 0.0843 & 0.0623 & 0.0754 & 0.106 & -0.242 \\
\hline & $(0.09)$ & $(0.09)$ & $(0.10)$ & $(0.10)$ & $(0.22)$ \\
\hline \multirow[t]{2}{*}{ Logged Sales } & -0.113 & 0.0177 & -0.0501 & -0.0522 & -0.113 \\
\hline & $(0.15)$ & $(0.18)$ & $(0.19)$ & $(0.18)$ & $(0.18)$ \\
\hline \multirow[t]{2}{*}{ Firm Age } & 0.00214 & 0.00224 & 0.00141 & 0.00124 & 0.00122 \\
\hline & $(0.00)$ & $(0.00)$ & $(0.00)$ & $(0.00)$ & $(0.00)$ \\
\hline \multirow[t]{2}{*}{ Prior CEO-Only Events } & 0.078 & 0.0658 & 0.132 & 0.0961 & 0.111 \\
\hline & $(0.11)$ & $(0.13)$ & $(0.14)$ & $(0.14)$ & $(0.14)$ \\
\hline \multirow[t]{2}{*}{ \% Held by Blockholders } & -0.00987 & -0.0111 & -0.0111 & -0.0108 & -0.0113 \\
\hline & $(0.01)$ & $(0.01)$ & $(0.01)$ & $(0.01)$ & $(0.01)$ \\
\hline \multirow[t]{2}{*}{ Constant } & 0.261 & -0.783 & -0.838 & -0.621 & -0.213 \\
\hline & $(1.30)$ & $(1.45)$ & $(1.55)$ & $(1.51)$ & $(1.40)$ \\
\hline Log Pseudolikelihood & -281.62 & -243.61 & -235.18 & -232.47 & -227.71 \\
\hline Pseudo $R^{\wedge} 2$ & 0.39 & 0.47 & 0.49 & 0.49 & 0.51 \\
\hline $\mathbf{N}$ & 2918 & 2918 & 2918 & 2918 & 2918 \\
\hline
\end{tabular}

Robust standard errors, clustered by firm, are in parentheses. Fixed effects for industry by SIC major sector are included in the model but not shown here.

$+\mathrm{p}<.1, * \mathrm{p}<.05, * * \mathrm{p}<.01, * * * \mathrm{p}<.001$ 